\title{
Sultan Abdel-Hamid's II Gift based on Family Memoirs:
} 1876-1909

\author{
By
}

Dr. Neven Mostafa Hassan Saad

Assistant Professor Modern History

Faculty of Arts, Menoufia University, Egypt

Mohammed Abdullah Mushabab Aal Muzher al-Asmari

Kingdom of Saudi Arabia

\begin{abstract}
Sultan Abdel-Hamid II is an important historical, yet controversial, figure. Some writings regarded him as a fair reformer, ruling a vast multi-ethnic empire with strength, intelligence and firmness. He faced Western and Jewish colonization and prevented them from establishing a national homeland in Palestine despite the weakness of the Ottoman state - the Sick Man of Europe. However, some viewed him as a tyrannical dictator who did his best for his country and for building a large army.

Concerning the importance of the subject, we find that it is a unique and special case, specially the gift from Sultan AbdelHamid II to the tribe of Ballasmer ${ }^{1}$ in southwestern Saudi Arabia and the northern city of Abha on the Sarawat mountain range. The envoy of Sultan Abdel-Hamid II reached the Arabian

\footnotetext{
${ }^{1}$ Ballasmer (geminated L) is a tribe of Rijal Al-Hajar, located in the southwest of Saudi Arabia. It is located north of the city of Abha on the Sarawat mountain range. It is about $100 \mathrm{~km}$ away from Abha. Ballasmer is at the heartland of Rijal Al-Hajar, having a triangular shape whose base is to the west and head to the east. Ballasmer tribes belong to two branches in Sarrah, Tuhama and Badia: They are bani Manbah al-Sham and bani Manbah al-Yemen. Bani Manbah al-Yemen is divided into the tribes of Al-Ubaid and Al-Midfah. The people of Al-Midfah were called bany Katheer. Aal Muzher alAsmari: Ballasmer tribe belongs to Asmar ibn Hajar bin al-Hanu bin al-Azd ibn al-Ghaouth bin Nabt bin Malik bin Zaid bin Kahlan bin Saba bin Shajab bin Yarob or Oraib bin Qahtan (for more see: Mahmoud Shaker, The Arabian Peninsula "Asir", al-Maktab Al-Islami, Damascus, p. 16, http://www.alnssabon.com/t41262.html, Ibn Hazm, Abu Muhammad Ali bin Ahmed bin Said bin Hazm al-Andalusi (d.456 AH). Lineage of the Arabs, Dar al-Kittab al-Alami, Beirut, $1^{\text {st }}$ ed, 1983. P.187, https://1asir.com/149984, http://www.alnssabon.com/t41262.html.
} 
Peninsula and was received with hospitality and ovation by Emir (prince) Ali bin Mohamed German, Emir of Ballasmer and Ballahmer. and Sent anumber of the delegation to the Sheikh Mushabab Aal Muzher al-Asmari. Hence, the Sultan's envoy presented a rifle to the Sheikh Mushabab Aal Muzhe al-Asmari. It was Ottoman-made during the reign of Sultan Abdel-Hamid II, dating back to $1326 \mathrm{AH}$, painted in silver and stamped with Sultan Abdel-Hamid's II seal. There was a writing of "Istanbul" under the seal and an Ottoman phrase translated as "Made at gunmills in Turkey"

\section{Introduction:}

Sultan Abdel-Hamid II was born on Wednesday, September 21, $1258 \mathrm{AH}$ corresponding to $1842 \mathrm{AD}, \mathrm{He}$ was the son of Sultan Abdul-Majid and his wife Tirimugan Qadin. ${ }^{2}$ He was educated at the Sultan's palace at the hands preeminent educators of his time in regard to knowledge and morality. He learned the Persian and Arabic languages. His step-mother, the second wife of his father, took care of him; she was sterile. She raised him well and presented her inheritance to him in a will.

After the deposing of his brother Murad ${ }^{3}$ on Thursday, August 11, $1293 \mathrm{AH}$, corresponding to August 30, 1876, he was elected as caliph, at thirty-four of age. Senior dignitaries, employees, ministers; both military and civilians, attended his coronation

\footnotetext{
2 Tirimugan, mother of Sultan Abdel-Hamid II, was born on 16/8/1819 and died on 3/10/1852. She was the fourth wife of Sultan Abdul-Majid. She was of Circassian strain; born in Caucasia, the Shayesug tribe. She was promoted, in 1849 , to the rank of third wife. Her daughter, Naima, died before the birth of Sultan Abdel-Hamid, aged two and a half years, from smallpox. Tirimugan died of tuberculosis at 33 years of age. She was buried in Murad V cemetery in Yeni Jameh. (Yilmaz Oztuna, History of the Ottoman Empire) Adnan Mahmoud Salman, Mahmoud Al-Ansary (translators). (Turkish, Istanbul, Faisal Funding Foundation, 1990). P. 95.

3 He is Murad V, son of Sultan Abdel-Mageed. He was born in $1256 \mathrm{AH}$, learned the French language, and got influenced by its culture. He was nominated as sultan after the overthrow of his uncle Abdul-Aziz in $1293 \mathrm{AH}$. When he heard about the killing of his uncle, the revolution of the Bulgarians and the rebellions in Bosnia and Herzegovina and Serbia, he got so nervous and showed signs of insanity. The Mufti of Islam issued a fatwa (ruling) to depose him. He was transferred to the palace of Garghan until he died in 1323 AH. He had eight children. For more: Refer to: Mohamed Kheir Falaha: The Ottoman Caliphate from the Cradle to the Grave. (an objective study showing states of sultans and their civilization of decorating, followed by rashness of the reckless, 2005), p. 68.
} 
Sultan Abdel-Hamid's II Gift based on Family Memoirs1876-1909.

ceremonies. Guns were fired all over the Ottoman Empire to mark the occasion. ${ }^{4}$

The accession of Sultan Abdel-Hamid II had a clear impact on the great efforts he made to upgrade the Ottoman Empire. Murad was unable to manage the affairs of the state or to appear before the people. The colonial countries were planning to attack the Ottoman Empire and divide its property. This was why AbdelHamid accepted the throne when offered by Medhat Pasha for the second time, and promised, at that time, to achieve three conditions; namely: the declaration of the Constitution, the establishment of the Shura (Islamic consultation), and the reappointment of the private secretariat of his brother Murad. ${ }^{5}$

Reforms of Sultan Abdel-Hamid II:

Sultan Abdel-Hamid II accomplished social and economic reforms; he tried to terminate the grievances of dwellers of the Ottoman Empire provinces (vilayets).

At the beginning of his rule, he used to follow up the news of the empire from within the palace; but he found that corruption had mushroomed throughout the country. Reform seemed out of reach, especially since the great European countries had made great progress. ${ }^{6}$ Under these difficult conditions, the Sultan tried to prevent the falling of the state. He succeeded, thanks to God and His care, for thirty years. ${ }^{7}$ This was why the great powers showed respect for him; for not indulging in pleasures and spending most of his time in carrying out the basic reforms. But,

\footnotetext{
${ }^{4}$ Ibrahim Bek Halim: The history of the Grand Ottoman Empire, known as The Halimi book of masterpiece on the history of the Ottoman Empire, the Foundation of the Cultural Books, Beirut, first edition, $1408 \mathrm{H}-1988$, p. 221, Ismail Yaghi: The Ottoman state in the modern Islamic history, 1416 AH 1996, p. 183.

${ }^{5}$ Rafiq Shaker al-Natsha: Sultan Abdel-Hamid II and Palestine, The Arab Foundation for Studies and Publishing, Beirut, 3rd ed, 1991, p. 69, Nahed Ibrahim Dasouki: Ottoman Centuries: The Rise and Fall of the Empire, Munshaat Al-Ma'aref (Knowledge Establishment), Alexandria, 2002, p. 58.

${ }^{6}$ Rafiq Shaker: Sultan Abdel-Hamid II and Palestine, p. 9,49.

${ }^{7}$ Gamal Abdul Hadi Masoud et al.: Errors that must be corrected in history, Ottoman State, C2, Dar Al-Wafaa, First Edition, 1416 AH,1995, p. 11.
} 
European countries got afraid of his reforms because he sought to treat the Sick Man. They attempted to get rid of him, as evidenced by the fact that two years after his accession to the throne, the British Prime Minister, Lord Salisbury, said: "The Sultan has only one wife; will he be another Soliman the lawmaker?". 8

It seems that Sultan Abdel-Hamid II benefited greatly from his uncle, Sultan Abdul Aziz, ${ }^{9}$ who was an example to him. The internal and external situations required a man enjoying political experience and great ability to solve problems. On the one hand, Westerners were calling for the constitution; adopting the Western slogans. On the other hand, rebellions in the Balkans had to be suppressed. As a result, the Sultan was keen to form popular councils to help the empire attain its duties. Therefore, he issued a decision on 5 Shawwal 1262 AH- October 24, 1876 declaring the Constitution. It was known in Ottoman history as "first conditionality". ${ }^{10}$ The purpose was to stymie foreign intervention under the pretext of reforming the conditions of Christians"11 after the revolution in the Balkans and the desire of the major colonial powers to exploit that revolution to divide the property of the Ottoman Empire". ${ }^{12}$

\section{Council of Emissaries:}

\footnotetext{
${ }^{8}$ Rafiq Shaker: Sultan Abdel-Hamid II and Palestine, p.49.

${ }^{9}$ Sultan Abdul Aziz, son of Sultan Mahmud II, was born in Istanbul in 1245 AH. He mastered the French language and practiced it. He loved equestrian and wrestling and ascended the throne of the Ottoman Empire in 1277 AH after the death of his brother Sultan Abdul Majeed. He had twelve sons. Refer to: Muhammad Khair al-Falah: The Ottoman Caliphate from the Cradle to the Grave, p. 68.

${ }^{10}$ Gamal Abdul Hadi et al., Errors that must be corrected in history, p. 11, Mohamed Kheir Falaha: The Ottoman Caliphate from the Cradle to the Grave. p. 69, Robert Mantrand: The History of the Ottoman Empire, part 2., Basher al-Siba'e, trans. Dar al-Fekr, $1^{\text {st }}$ ed, 1993, p. 164.

${ }^{11}$ On December 23, the ambassadors of Germany, England, Russia, Austria and Hungary met in Istanbul to discuss the plight of the Balkan Christian republics against the Ottoman Empire. Refer to Kamal al-Said Habib: Minorities and Politics in Islamic Experience from the Beginning of the Prophetic State to the End of the Ottoman Empire (621-1908), Madbouli bookshop, 1, 2002, $1^{\text {st }}$ ed. 2002, p. 445.

${ }^{12}$ Kamal Al-Saeed: Minorities and Politics, p. 445, Gamal Abdul Hadi: Errors that must be corrected in history, p. 11.
} 
Sultan Abdel-Hamid's II Gift based on Family Memoirs1876-1909

In any case, the parliament consisted of two chambers: the first was elected by the people. This council was called Mabouthan (the Emissaries). The second was appointed by the state. It was called council of dignitaries (the Senate). Sultan Abdel-Hamid appointed Medhat Pasha as prime minister, stressing the observance of Islamic law in all matters.$^{13}$

He issued a basic statute of the state, including one hundred and nineteen articles on 4 Dhual-Hijjah 1293, AH-1876, guaranteeing for all the citizens of the state freedom and equality before the law. It permitted the freedom of education and made it compulsory on all Ottoman subjects, as well as freedom of publications. It also specified the competence of the Councils of Emissaries and Dignitaries, ${ }^{14}$ methods of election, giving all subjects ottoman names and regarding the state as one unit. The Sultan also ordered the annulment of property confiscation, torture during interrogation, ridicule of some of his people, deposing any judge unless there is a legitimate reason. $\mathrm{He}$ stressed the importance of the principle of consultation. ${ }^{15} \mathrm{~A}$ researcher notes that the Ottoman constitution, proclaimed by Sultan Abdel-Hamid II, was a revolution in Ottoman and Islamic history, because it introduced a new secular reference that differs from the Islamic authority, which makes Islamic law alone the sole source of legislation. This is the first comprehensive secular legislative attempt in the Islamic countries. ${ }^{16}$ Nahed Ibrahim maintains that the question of the Sultan's acceptance of the Declaration of the Constitution is the beginning of a new era of

\footnotetext{
${ }^{13}$ The Constitution states that the Islamic religion is the religion of the state. All the religions known in the Ottoman Empire are free and under the auspices of the state, with the privileges of the different community. The Turkish language is the official language, and the Sultan is sacred and is the successor and ruler of the Muslims. Refer to: Kamal AlSaid Habib: Minorities and Politics in Islamic Experience, p. 447.

${ }^{14}$ For further details on the powers of the Senate (dignitaries) and Emissaries, Refer to Nizar Kazan: Sultans of Bani Othman between the fighting of the brothers and sedition of the Janissary, Lebanese Thought House (Beirut, 1, 1992, p. 72, 73.

${ }^{15}$ Gamal Abdel Hadi: Errors that must be corrected in history, $\mathrm{p} 12$.

${ }^{16}$ Kamal Al-Said Habib: Minorities and Politics in Islamic Experience, p. 447.
} 
prosperity, because the Armenian and Greek Patriarchs have been called upon on the basis that the Constitution guarantees equality among believers of religions. ${ }^{17}$ In this way, Sultan Abdul Hamid II demonstrated a reformist spirit when he asked Medhat Pasha to promulgate the Basic statute seemingly inspired by the Constitutions of Belgium, France, England and the United States of America. In short, the Sultan enjoyed constitutional rights like any constitutional governor. He minted money in his name, had his name mentioned in Friday sermons and forged agreements. ${ }^{18}$

On February 14, 1878, Sultan Abdul-Hamid II dissolved the Parliament to an indefinite date and suspended the constitution of 1876. This led to controversy. A group of scholars maintained that Sultan Abdel Hamid lacked trustworthy men; plots were being yarned against him from all directions including men of the Ottoman Empire, including Medhat Pasha, who opposed these reforms and conspired to depose the Sultan. He sought to overthrow the system of succession (caliphate) to adopt the nonreligious European system. So, the Sultan deposed him on Moharam, 211294 AH- 5 February 1877, and tried to seize all power in his hands gradually. The administration has been characterized by absolutism. ${ }^{19}$ Some modern scholars maintain that there were reasons that prompted Sultan Abdel-Hamid to dissolve the constitution of 1876 and return to the system of absolute rule; because the constitutional government will create many problems in the future and that was why it was suspended. ${ }^{20}$ That absolute or authoritarian rule was exacerbated

\footnotetext{
${ }^{17}$ Nahed Ibrahim: The Ottoman Centuries, p. 581.

18 Abdel-Aziz Muhammad Al-Shennawi: The Ottoman Empire is a calumniated Islamic State, the Anglo-Egyptian bookshop, Cairo, 1980, p. 41.

${ }^{19}$ Ismail Yaghi: The Ottoman State in Modern Islamic History, p. 12, Abdul Aziz AlShennawi: The Ottoman State is a calumniated Islamic State p.45. Abdelaziz Awad. The Ottoman administration in Syria, 1864-1914, Dar al-Ma'aref, Egypt, 1969, p. 45.

${ }^{20}$ Nahed Ibrahim: The Ottoman Centuries, p. 581, Robert Mantrand: The History of the Ottoman Empire, p.165.
} 
Sultan Abdel-Hamid's II Gift based on Family Memoirs1876-1909

by the suspicions of Sultan Abdel-Hamid II when he took over the throne of the Ottoman Empire following two successive deposings in one year. The first was against his uncle, Sultan Abdul Aziz, who committed suicide a few days later. The second was against his brother Murad V, who was deposed after he turned insane. These two incidents greatly influenced the course of Sultan Abdel-Hamid during his long rule.

$\mathrm{He}$ appointed more spies to monitor the movements of employees, excluding no one, even the prime minister. He commissioned these spies to submit reports to him. ${ }^{21}$

The question is: Were there justifications for Abdel-Hamid II to abolish the constitution? In his memoirs, he said: "Medhat Pasha cared for nothing other than the benefits of the democratic constitutional rule in Europe. He did not investigate the reasons for this constitutional rule or its other influences ... I think that the basics of this constitutional rule are not suitable for every people and every national structure. The environment in which institutions operate and their compatibility with the nature of institutions are the basic condition for these institutions to bear fruit. The institutions that the organizations set forth, from the Sultan's point of view, were not suitable for the historical circumstance of the state, nor were they suitable for an Ottoman state of multiple nations and nationalities. ${ }^{22}$ Thus, it may be maintained that such despotism and centralism were vital for the unity and survival of the Ottoman Empire. Muslims of the Ottoman Empire, who tended to preserve the empire and Islam in the face of European challenges, liked this. Sultan Abdel-Hamid II himself belonged to the Islamic trend. ${ }^{23}$ All this justifies why the Sultan had disliked the practices of the Constitution. ${ }^{24}$ It is

\footnotetext{
${ }^{21}$ Abdel-Aziz Mohamed Awad: The Ottoman Administration, p. 45, Ismail Yaghi: The Ottoman Empire in Modern History, p. 185.

${ }^{22}$ Kamal Habib: Minorities and Politics in Islamic Experience, p. 448.

${ }^{23}$ Ismail Yaghi: The Ottoman Empire in Modern Islamic History, p. 158, Kamal Habib: Minorities and Politics in Islamic Experience, p. 185.

${ }^{24}$ Nizar Kazan: Sultans of Bani Othman, p. 73.
} 
Dr. Neven Mostafa Hassan Saad i/ Mohammed Abdullah Mushabab Aal Muzher al-Asmari

important to point out the important opinion of Mary Melz Patrick in her book Pages from Turkey's social, political and Islamic history. She blamed Sultan Abdel Hamid II. The day the Constitution was annulled, Medhat Pasha's martyrdom began. She accused him of getting rid of the important man who wanted to serve the Ottoman Empire; he spent the rest of his life tormented in exile, and he was martyred in the cause of his principles. It is also understood from her book that the Constitution of Medhat Pasha, in the eyes of Abdel-Hamid, was nothing more than a trick, with which he would forge alliance with Western countries. Scholars of Islamic law and state leaders including Medhat used to pin hopes on the Constitution as the only savior of the crisis of the Ottoman Empire. ${ }^{25}$

Mary adds that reformists believed in his sincerity and trusted his good intentions; but he failed them by suspending the constitution suddenly. She also maintains that he tried to depose Medhat Pasha because he feared the love of the Ottoman people for him. He exiled him to the city of Taif, and four years later, the Sultan held a council of scholars of the Shari'a to try him on the assassination of Sultan Abdul-Aziz. Only then did AbdelHamid got relieved. ${ }^{26}$ The Council, which met two months later and, based on the will of the Sultan, suspended the rest of the provisions of the articles of the reformist Constitution of Medhat Pasha. The parliament met again only in 1908, that is thirty years after the incident. ${ }^{27}$ But the researcher confirms that what was said about Sultan Abdel-Hamid II does not live up to the level of the historical fact; because Sultan Abdel-Hamid, at the beginning of his rule, faced the tyranny of Medhat Pasha, and other ministers. Their intensive policy of Westernization, led by the New Ottoman Society, which included an educated elite

\footnotetext{
${ }^{25}$ Mary Malz Patrick: Pages from Turkey's social, political and Islamic history, Izz al-Din Establishment 1, 1407, 1986, p. 112, 113.

${ }^{26}$ Mary Malz Patrick: Pages from the History of Turkey, p. 116, 117.

${ }^{27}$ Ibid., P. 117.
} 
Sultan Abdel-Hamid's II Gift based on Family Memoirs1876-1909

influenced by the West, was so severe. Freemasons ${ }^{28}$ were able to recruit them to serve their objectives. The tyranny of ministers was so strong that Medhat Pasha wrote to Sultan Abdel-Hamid, in his early reign, in 1877 , saying:

"Our purpose of the Constitution is only to end tyranny, specify your Majesty's rights and duties, appoint ministers, and safeguard all people's freedom and rights for the country to flourish. I obey your orders if they are not contrary to these things ...". Sultan Abdel-Hamid II comments: "I found out that Medhat Pasha made of himself a ruler and a guard to me. He was so far from democracy and closer to tyranny. ${ }^{29}$

Medhat Pasha and his Masonic friends used to drink wine. Sultan Abdel-Hamid adds: "It is known that the liberals of that era; poets and writers, gathered on the evening of the decree of the Basic statute at the palace of Medhat Pasha, not to talk about the affairs of the state, but in matters of drinking and boisterous acts, while drinking wine. Medhat Pasha was addicted to wine since his youth, and well-known for this ... When Medhat Pasha rose from the table, he got out leaning on the arms of others so as not to fall on the ground ... ". ${ }^{30}$

Regarding the story of indicting of Medhat Pasha of killing the Sultan; Sultan Abdul Hamid set a committee to investigate the matter. He appeared before the court that sentenced him to death". ${ }^{31}$

\footnotetext{
${ }^{28}$ Freemasonry is the cultural and economic reservoir that conspires against the Islamic world. It is one of the greatest secret societies known as freemasons. Its origins are unknown. Its ideas are derived from Jewish and Christian sources and do not recognize religions. Masons claim that it is a philosophical institution that brings good to humanity. Their mission is briefly tempting politicians with money. They tried to distract people from religious zeal. Refer to: Mohamed Kheir Falaha: The Ottoman Caliphate from the Cradle to the Grave, p. 76.

${ }^{29}$ Ali Mohammed Al-Salabi: The Ottoman State: Factors of Promotion and Causes of Fall, Islamic House for Distribution and Publishing, First Edition, 1421 AH-2001, p. 402.

${ }^{30}$ Medhat Pasha, at wine councils, revealed the secrets of the Ottoman Empire. These secrets were spread among the people of Istanbul. Refer to Ali al-Salabi: The Ottoman Empire, p. 403.

31 Ali al-Salabi: The Ottoman Empire, p. 403.
} 
Dr. Neven Mostafa Hassan Saad / Mohammed Abdullah Mushabab Aal Muzher al-Asmari

Accordingly, the researcher concludes that charges against Abdel-Hamid were not true. He was against the constitution, which was defined as conditionality, that is, requiring the ruler to renew his authority; a thought from the West. Therefore, he was against those who called for the constitution led by Medhat Pasha. He criticized this minister and did not change his position towards constitutional rule on the grounds that the Ottoman state gathered different peoples, and said: "What happened when conditionality was declared? Have debts declined? Were there many roads, ports and schools? Is personal security prevalent? Are people now more well-off? Have deaths decreased and births increased? Has global public opinion supported us more than before?

The beneficial medicine becomes a venom if it is in the hands of non-doctors, or those who do not know how to use it". ${ }^{32}$

Abdel-Hamid faced internal and external conspiracies. He was surrounded by a large number of conspirators as the European countries were keen to thwart his attempts to save the dilapidated state, which he tried hard to upgrade. The empire began, ten years before, to slowly recover; many schools and hospitals spread in Istanbul, administrative institutes were founded in order to prepare a new generation of students for public jobs. He established the first Ottoman medical school and equipped it with his own funds ${ }^{33}$ and expanded military schools. The establishment of Rashidia schools was launched, while the first preparatory school in Istanbul was inaugurated in 1875. The state tax imposed by the state in 1884 helped the establishment of schools in the state centers, and the state was able to impose more control over its provinces". ${ }^{34}$ The purpose of the establishment of these schools was that he saw that the national trend influenced by Western thought was prevalent in these

\footnotetext{
${ }^{32}$ Ibid: p, 405, 406.

${ }^{33}$ Rafiq Shaker: Sultan Abdel-Hamid II and Palestine, p. 58.

${ }^{34}$ Abdul Aziz Mohamed Awad: Ottoman Administration in the State of Syria, p. 40.
} 
Sultan Abdel-Hamid's II Gift based on Family Memoirs1876-1909

schools. So, the Sultan had to intervene in its affairs and ordered the exclusion of literature and general history from the study, because they were a means of Western literature. Lessons of jurisprudence, interpretation and ethics were in the programs of study, limited to teaching only the curricula of Ottoman and Islamic history. He ordered schools to serve Pan-Islamism", ${ }^{35}$ and developed telegraphy used first by the allied forces in the Crimean war. He founded a ministry for post and tried to identify the European West. He reformed the judiciary implementing reforms in an autocratic manner, especially in the financial and civil spheres, which needed to be developed". ${ }^{36}$

\section{Military Reforms:}

Sultan Abdel-Hamid II realized the need to pay attention to the army after the Russian-Ottoman war. Its needs had to be met. It needed more armament and teaching the soldiers and officers the modern rules of war. This is because the Ottoman Empire was pushed to this war by Medhat Pasha; without being militarily ready. Roads were not secure either, while financially the Ottoman Empire was not ready for war. ${ }^{37}$ In spite of the fact that Sultan Abdel-Hamid inherited a debt-laden heritage; he felt that it was necessary to take care of the army, even if at the cost of the treasury, because the state could not be saved from foreign ambitions except by a large army. ${ }^{38}$

Thus, military education was completed with the utmost care from Abdel-Hamid; the military college, the military and naval engineering schools and the military medical school were

\footnotetext{
${ }^{35}$ Ali al-Salabi: The Ottoman Empire, p. 426. Sultan Abdel-Hamid II reorganized the Royal Schools, which served as the main center for civic education in the country, and expanded them to accommodate large numbers of students. Refer to: Nahed Ibrahim: The Ottoman Centuries, p. 601.

${ }^{36}$ Nahed Ibrahim: The Ottoman Centuries, p. 601.

${ }^{37}$ The Ottoman army, which fought the war against Russia, was a group of regiments. The number of officers was very small, while the Russian army numbered half a million. See: Orhan Mohammed Ali: Sultan Abdel-Hamid II and the events of his reign, Istanbul, 2008.p. 124.

38 Ibid., P. 124.
} 
expanded. He also established eighteen official educational institutes in the fields of finance and police.

The School of Military Engineering and Military Medical Schools had more graduates than those of all senior civil schools. ${ }^{39}$

In this way, Abdel-Hamid was able to find a balance between military and civil education. ${ }^{40}$ At the same time, he separated the civil authority from the military, and recruitment was done by drawing lots of those in charge of military service. ${ }^{41}$ According to one researcher, Sultan Abdel-Hamid allowed some nonMuslims to join military colleges. It is likely that at the military academy there were eleven Jewish students, twenty Greek students and two Armenians. This was due to the religious tolerance of the Sultan. ${ }^{42}$ Through information about the admission of some foreigners to the Ottoman army, we can conclude that the Sultan did not accept the idea of subjecting non-Muslims to military service.

In his memoirs, he stated that the admission of non-Muslims caused a lot of trouble and problems, because they might convert to Islam, and the major states would not accept this. Then, there were other caveats, such as the possibility of their request to establish churches in the military barracks and the appointment of some priests to pray. Abdel-Hamid said this would be more serious, because there would be an army of Bulgarians and Romans in the Ottoman Islamic army. In case of recalcitrance, these forces would fight the Islamic Army, especially since the Christians in the Ottoman Empire were closely linked to the

\footnotetext{
39 John Patrick: The Ottoman Centuries, The Rise and Fall of the Turkish Empire, Translated by: Nahed Ibrahim Desouki, Al-Maaref Establishment, Alexandria, 2002.p. 601, Ali Ahmed Abbas: Sultan Abdel-Hamid II 1293 - 1326 AH / 1876-1909, unpublished doctoral thesis, Faculty of Education, University of Omdurman, Sudan, 2017. p. 179.

${ }^{40}$ Memoirs of Princess Aisha Osman Ogli: My Father Sultan Abdel-Hamid II,: Saleh Saadawi, (translator). Dar al-Bashir, first edition, 1411 AH-1991. p.22

${ }^{41}$. It seems that some of the military service officials were provoking the state when the lottery was conducted in some areas. See Ismail Yaghi: The Ottoman Empire in Modern Islamic History, p. 186.

${ }^{42}$ Ali Ahmed Abbas: Sultan Abdel-Hamid II, p. 180.
} 
Sultan Abdel-Hamid's II Gift based on Family Memoirs1876-1909 major countries. ${ }^{43}$ Therefore, the researcher maintains that the Sultan admitted some officers of the Jews and Christians to the Ottoman army, presumably at the late era of the Sultan, who wanted to calm the pending revolution. It can also be argued that the number of these officers were not a threat to the Ottoman army because they were few.

In any case, the Higher Military Academy was so successful that the average number of its graduates was 151 officers a year, and almost the same number of graduates of the Military Medical School, In 1897, the number of military schools ${ }^{44}$ amounted to 29 , six in Istanbul, and one in each major state, while the number of students was about $8,247 .{ }^{45}$

Sultan Abdel-Hamid wanted only culture of the West along with modern sciences. This was why he invited some German generals to train the Ottoman army according to requirements of the age. ${ }^{46}$

In fact, Germany (Prussia) was the only suitable ally. ${ }^{47}$ It sought the pleasure of the Sultan. ${ }^{48}$ In October, 1898 William II, Emperor of Germany, bid an official visit to Turkey. He was the only European ruler to be received by Sultan Abdel- Hamid II. ${ }^{49}$

\footnotetext{
43 Sultan Abdel-Hamid II: My Political Notes (1891-1908), al-Resala Foundation, Beirut, Lebanon, second edition, $1399-1979$, p. 103.

${ }^{44}$ In addition to the civic schools, there were military schools that qualified their students to join the military colleges. See: Ali Ahmed Abbas: Sultan Abdel-Hamid II, p.180.

45 Ibid., P. 180.

${ }^{46}$ Amani Jaafar al-Ghazi: Sultan Abdel-Hamid II, the calumniated and his position from the hijab (veil) of women. An analytical historical study, Journal of Oriental Studies, p. 55, 2015, p. 260, Ahmed Abdul Rahim Mustafa: On Origins of Ottoman History, Dar Al Shorouk, Cairo, $3^{\text {rd }}$ edition, 2003, p.242, Soliman bin Saleh. How the Ottoman Empire fell, Dar al-Qasim, Riyadh, $1^{\text {st }}$ ed., 1420AH, p. 29.

47 This was revealed after the Ottoman War against Russia (1294 - 1295 AH / 1877 - 1878) It revealed the very weakness of the capabilities and equipment of the Ottoman army. In the face of this problem Sultan Abdel-Hamid II searched for a solution to strengthen the Ottoman army away from France and England. In this regard, his attention was towards Germany, that strong European state, which seemed to him having no designs of his empire, especially after appearing as a strong military state after the war in $1287-1870$ with France. See also: Siham Mohamed Hendawi: The Historical Development of GermanOttoman Relations (1293 AH / - 1327 AH1876 / 1909 ) Confidential Documents, Dar Ninawa for Studies, Publishing and Distribution, Syria-Damascus, $1^{\text {st }}$ ed, 2015, p. 106.

48 John Patrick: The Ottoman Centuries, p. 627.

49 Ibid, p. 221.
} 
Dr. Neven Mostafa Hassan Saad / Mohammed Abdullah Mushabab Aal Muzher al-Asmari

In the 1830s, Prussian officers served as trainers in the Ottoman army, including Helmut von Moltke. Germany was not eager to extend its control over the Ottoman Empire, so Abdel-Hamid sought an alternative to the traditional policy of relying on Britain. Also, the German army enjoyed great prestige, so Germany seemed to be the ideal ally to develop the empire. ${ }^{50}$

An Ottoman document attests to the extent of cooperation between the Germans and the Ottomans during the reign of Abdel-Hamid II, making use of such relations. ${ }^{51}$

In 1882, Abdel-Hamid brought in a number of specialized German generals, including von Draculge, von Hofze, and Kamp Huff. They trained various Ottoman groups on the latest weapons of the age. Two missions were sent in the Bismarck era, the Autocoller mission, and the mission of von Dergulach. The Ottoman army became well armed with a large amount of German weapons in 1887, after Luffy and Mozar firms got a deal with the Ottoman state to supply the Ottoman army with weapons. Germany, thus, had great sympathy within Ottoman public opinion, and Turkey had confidence in Germany and a permanent fascination with German military art. General von Druckulge said that the Ottoman army had become the number one army. There was no army superior to it. The Sultan also sent military missions to Germany. ${ }^{52}$ In his memoirs, he attested that

\footnotetext{
50 Ibid, p. 222.

${ }^{51}$ Political and military relations between Germany and the Ottoman Empire arose before the unification of Germany. These relations began officially for the first time under the reign of Sultan Mahmud II (1808-1839), who asked the Prussian government to let the Ottoman Empire benefit from the experience of its officers in organizing the army. Von Moltke was to do the job. For further details, see: Makram Abdel Fattah Abdel Khaliq: "Ottoman Document on German Ottoman Relations under the Sultan Abdel-Hamid II Study and Translation," Journal of the Faculty of Languages and Translation, Al-Azhar University, issue 31, 2000, p. 387.

${ }^{52}$ Rubier Mantran. The History of the Ottoman Empire, p. 224, Yusuf Hussain Yousef: The Reasons for dethroning Sultan Abdel-Hamid II 1876-1909, unpublished Master Thesis, Faculty of Arts, Yarmouk University, Jordan, 2000, P. 20. Seham Mohamed Hindawi: The Historical Development of Ottoman German Relations. P. 107, 109.
} 
Sultan Abdel-Hamid's II Gift based on Family Memoirs1876-1909

the German emperor praised the Ottoman officers who received military science in his country and were in constant progress. ${ }^{53}$

The Sultan believed that the emperor was wrong because the ambassador's report in Berlin reported that few Ottoman officers had focused on studying, many of whom were not worthy of praise due to their misbehavior; ${ }^{54}$ but events refuted the views of those malignant ones and absolved the Sultan from the charges that he was a radical who disliked change. ${ }^{55}$ The evidence is his saying: "The Pasha's sons' receiving military science in Prussia cost us a great deal, but it created a good impression abroad. In this way, we prove that we did not spare anything in order to keep our army at the required level" ..$^{5}$

It seems that Germany was not the only country to which Turkey turned. Although Sultan Abdel-Hamid was not inclined to France, ${ }^{57}$ he loved French culture, which was learned by naval officers. Until 1871, the French army was the greatest army in the world. It was replaced by the German training system. AbdelHamid rightly mentioned that the golden age of the history of Turkey was in recent years. Reforms in the era of his predecessors Abdel-Aziz and Abdel-Hamid Agha were due to the French reforms.

Abdel-Hamid attested that military schools were under French influence. ${ }^{58}$ This lasted up to 1900 s when the Ottoman army took its equipment from France and Germany until Germany was largely replaced by France. Germany acquired a sort of

53 Sultan Abdel- Hamid II: My Political Notes, p. 58.

54 In his memoirs, Abdel-Hamid pointed out that Ottoman officers who went to Germany got addicted to drinking alcohol; in addition to learning some anti-moral practices. They should have adhered to Ottoman customs and pure faith in God because these were the descriptions of the ideal soldier. See: Sultan Abdel-Hamid II: My Political Notes, pp 5859 .

${ }_{55}$ Ismail Yaghi: The Ottoman Empire, p. 186.

${ }_{57}^{56}$ Sultan Abdel-Hamid II: My Political Notes, p.58.

${ }^{57}$ Abdel-Hamid was afraid of France for being a republic and for promoting revolutionary ideas. See: Yilmaz Oztuna: Encyclopedia of the Ottoman Empire political, military and civilization, p. 410.

${ }^{58}$ Sultan Abdel-Hamid II: My Political Notes, pp. 139. 
Dr. Neven Mostafa Hassan Saad / Mohammed Abdullah Mushabab Aal Muzher al-Asmari

monopoly in the arms trade with the Ottoman Empire. Arms deals and trade with the Ottoman Empire became high on the list of trade and relations between the Germans and the Ottomans. The Ottoman Empire, until World War I, became Germany's most important customer in the purchase of weapons of all kinds. ${ }^{59}$ The army was equipped with the most modern weapons. The Sultan spent on the submarine experiments in Istanbul before England had a single submarine. He opened a school at his palace for the preparation of the telegraph staff to manage the telephone network for military purposes. This led to several victories after a series of military defeats as one of the researchers argued. ${ }^{60}$

The Ottoman army, in 1877, was considered the fourth army worldwide, preceded by Germany, Russia and France. It had about 700 thousand soldiers under arms and modern weapons. In 1908, there were 535 thousand gendarmerie forces and Hamidiyah militias. In the same year, the budget of land forces amounted to seven millions of golden liras. The army of the organizations was divided into seven large units, each called "army" while the centers of these armies, according to the sequence of numbers, were Istanbul, Aderna, a division in Mecca and Tripoli. The ranks of the commanders of the army were a field marshal or lieutenant general. ${ }^{61}$ The army had, in the event of war, 18 infantry, seven cavalry, and 3 artillery divisions. ${ }^{62}$

The military service was compulsory under the laws of 1888 and 1904. There was no reserve officer system and the service was up to 6 years, while call was made in time of war. Each year the state trained 70,000 people; the soldier who wished to continue the military could have stayed in the army. Because of the

\footnotetext{
${ }^{59}$ Mantrand: History of the Ottoman Empire, p. 223, Siham Mohamed Hindawi: Historical Development of German Relations,

${ }^{60}$ Muwafaq ibn al-Marja: Awakening of the sick man "Sultan Abdel-Hamid and the Islamic Caliphate", p. 123.

${ }_{61}$ Yilmaz: Encyclopedia of the Ottoman Empire, p 414, 415.

${ }^{62}$ Orkhan Muhammad Ali: Sultan Abdel-Hamid II, p. 125.
} 
Sultan Abdel-Hamid's II Gift based on Family Memoirs1876-1909

application of the reserve officers system, employees did not apply military. ${ }^{63}$

The cavalry units were small and consisted of three brigades. In 1903, each brigade was assigned one additional cavalry battalion, and the number of battalions increased to seven. Control units assigned one control company for each army. The Control battalions and companies were related to marshaldom of Toubkhana troops in time of war. Each army had one company while the Fifth Army had two additional transport companies, and five fire brigades. ${ }^{64}$

The artillery was divided into 15 brigades, containing 35 artillery battalions, all of which were 271 batteries, and each battery contained 6 guns, both in times of peace or war. Thus, the artillery consisted of 1,626 mobile guns; divided as follows: The first army had 39, the second army 58, the third army 77, the fourth army 39, the fifth army 26, the sixth army 17, the seventh army 7 , the Tripoli brigade6, the Hegaz brigade two batteries, castle artillery 146 batteries. The first army had five companies of control soldiers, the second army had two, the third had one, the 4th had one, and the Fifth Army had one, the sixth had one, and the seventh had one. On the other hand, there were 63 platoon sergeants forming a brigade of the command related to marshaldom of Toubkhana. It trained specialized workers and skilled labor leaders. ${ }^{65}$

The arms were transported to Mecca by foreign ships from different countries. ${ }^{66}$ Thus, the empire could mobilize 1683,000 land troops in the times of general mobilization. It is worth

\footnotetext{
${ }^{63}$ Yilmaz: Encyclopedia of the Ottoman Empire, p. 415.

${ }^{64}$ In peacetime, there were between 400 and 600 troops for each company, while a cavalry unit consisted of 60 to 120 horses. See ibid., P. 417.

65 Ibid., P. 417.

66 Suhail Saban: Arms Trade in the Arabian Peninsula and the Gulf from the Ottoman Archive 1898-1910 / 1310-1328, King Fahd Library Journal, vol. 10, p. 2, 2005, p. 277.
} 
Dr. Neven Mostafa Hassan Saad / Mohammed Abdullah Mushabab Aal Muzher al-Asmari

mentioning that the Egyptian forces were not counted in this number as England controlled Egypt . ${ }^{67}$

In addition, the gendarmerie had a total of 544 infantry and 200 cavalry. In 1908, the army had 410,000 regular soldiers and 50 thousand gendarmerie under arms. The Hamidiya battalions were as follows: the light-movement battalions formed by the Kurdish volunteers in eastern Anatolia. England and France used this type of troops. These forces then rebelled against Sultan AbdelHamid. After the declaration of the constitution ( conditionality), the formations of land forces were 40 regular wartime units . ${ }^{68}$ Through this army, Sultan Abdel-Hamid managed to fortify the sensitive sites in the Bosphorus. The army was then able to win the Ghanak battle in World War I against Britain and its allies. ${ }^{69}$ Suffice it to read the pages of Princess Aisha's diary to learn about the capabilities of this army during the official parade of the army.

As for the Ottoman guns, ${ }^{71}$ a number of researchers studied the extent to which the industry had flourished during the Ottoman period. The Leventus Museum in Nicosia keeps three Ottoman rifles, two of which are about $122.5 \mathrm{~cm}$ long; The third is the long type used in the siege of cities with a length of $157.5 \mathrm{~cm}$. Each of these rifles consists of a metal pipe and a piece of wood at the bottom, and the barrel of fire called "the house of gunpowder"; the ignition chamber, the trigger or shooting. Then we have handle of the rifle followed by the butt, which is base of

\footnotetext{
${ }^{67}$ Yilmaz: Encyclopedia of the Empire, p. 418.

${ }^{68}$ Ibid, P. 418.

69 Orkhan Muhammad Ali: Sultan Abdel-Hamid II, p. 125.

${ }^{70}$ For more details on the official reviews, see: Memoirs of Princess Aisha Osman Ogli: $M y$ Father Sultan Abdel-Hamid II, p.116.

71 The rifle is a weapon of war known as gunpowder after the gunpowder it fires. It is a lightweight single shotgun with a stabilized lining and is used to shoot from the shoulder at close distances. See: Bader Mohammed Abdelaziz Badr: Ottoman Firearms at the Levantine Museum in Nicosia and the Middle Ages in Limassol, Cyprus "A Comparative Archaeological Artistic Study", Proceedings of the Fifteenth Congress of the General Union of Arab Archaeologists, Jeddah, 1st, 2012. P. 971.
} 
Sultan Abdel-Hamid's II Gift based on Family Memoirs1876-1909.

the rifle for leaning on in the case of use. The into the shoulder of soldiers to repel reaction of bullets shot. ${ }^{72}$

Long guns were used in battles inside castles, in the hands of cavalry and in royal reviews. This type of guns was devoid of decoration and was limited to the color of the wood. There was another type that was carried by the Ottoman Sultan during the parades in the palace. ${ }^{73}$

The parade rifles were known as ornamental rifles, with a huge decorative wealth of yellow, gold, silver and gems. ${ }^{74}$ Infantry rifles were mounted on a wooden butt supported by the shooter to his chest. They were kindled by a fuse of gunpowder placed in the upper section of a serpentine pipe. With ignition, the fuse got ignited and bullets were shot. The Ottoman army used this type of rifle against their opponents and was called tafank.

A rifle was also invented with a flint fire-steel provided with a hammer and decorated with the beak of the cock holds a piece of flint. When the hammer was pulled, the flint was hit by a steel plate with a spark that ignited the torch. ${ }^{75}$

Small-barreled firearms manufacturers called the little rifles carbines, a term based on the German term "Karbiner", meaning the small rifle. The rifles were characterized by high-quality, high-precision, and long-range. This type of rifle was redesigned in the 19th century where the gun is fed from the back of the barrel. $^{76}$

The explosive material was gunpowder and its manufacture was easy in the case of securing sulfur, which was of little availability compared to other materials. In the absence of gunpowder, no firearm can be made. The powder in the barrels

72 Abdul Aziz Badr: Firearms, p. 970.

73 Mohammed Mahmoud Ali Al-Jahini: "The Art of Rifle Decoration in the Ottoman Period", Journal of the Faculty of Archeology, South Valley University, Qena, p 6, 2011, p. 281.

${ }^{74}$ Ibid., P. 382.

75 Badr Abdul Aziz: Ottoman Firearms, p.972.

76 Ibid., P. 973. 
can be ignited if the closed buildings are to be blown. But dropping bombs by gunpowder gave birth to firearms. ${ }^{77}$

In addition to the army, Sultan Abdel-Hamid II supported the fleet and supplied it with submarines. He also fortified fortresses of the war on the Bosphorus and Dardanelles. ${ }^{78}$ At the time of his accession to the throne, Abdel-Hamid received eight warships from his uncle Sultan Abdul Aziz. He brought the number to twenty-three battleships and seventy-eight auxiliary ships. He purchased two large torpedoes from Germany and six torpedoes from France and England.$^{79}$

In 1876, the revolution in Herzegovina erupted and was incited by Montenegro and Serbia, but the revolution was suppressed. The Sultan wanted to prevent the European countries from intervening. When these revolutions failed to achieve their goal, Russia explicitly declared war on the Ottoman Empire because of Romania. The Ottomans were obliged to sign the unfair San Stefano Treaty against the Ottomans after the state lost parts of it in this war ". ${ }^{80}$ But these European countries did not keep armfolded while Russia devoured large parts of the Ottoman Empire; the Berlin Treaty was forged and signed in Berlin, apparently to limit the influence of Russia, but its implicit end was more

\footnotetext{
77 Yilmaz: Encyclopedia of the Ottoman Empire, p. 403, 404.

78 Mahmoud Thabet Al-Shazli: The Eastern Question: A Documentary Study on the Ottoman Caliphate, 1299-1923, Wahba Library, Cairo, $1^{\text {st }}$ ed. 1409 AH, 1989, p. 163.

79 Orkhan Muhammad Ali: Sultan Abdel-Hamid II, p. 126, Yilmaz: Encyclopedia of the Ottoman Empire, p. 189.

${ }^{80}$ England intervened to prevent Russia from occupying Istanbul. Russia and the Ottoman Empire held the Treaty of San Stefano, and the Russian delegate provided conditions:

-Demarcation of the borders of Montenegro, capital of the Serbs, independence of Bulgaria administratively as well as Romania, pledge of the Sublime Porte to protect the Armenians, paying a fine of 245 million lira, and opening Bosphorus for Russian ships. For more details: Refer to: Yilmaz Ozatuna: Encyclopedia of the Political, Military and Cultural History of the Ottoman Empire, Vol. III, Translated by: Adnan Salman, Arab House for Encyclopedias, First Edition, 2010, p. 121. Ali Al-Salabi: The Ottoman Empire, p. 412, 413.
} 
Sultan Abdel-Hamid's II Gift based on Family Memoirs1876-1909

dissection of the state, and the distribution of its property to colonists". ${ }^{81}$

The Ottoman Sultan Abdel-Hamid II realized that he, alone, could not stand up to Europe. He was so afraid of European countries, he tried to preserve what remained of the state's possessions, and was afraid of the revolution of some minorities that could be supported by other European countries. To face such challenges, he tried to found the Pan-Islamic movement to rally all Muslims around him. Pan-Islamism was accepted by Muslims who witnessed weak allegiance among people of the nation and secular currents, as well as false lies and promises. The Sultan considered that Pan-Islamism would attain great ends against enemies of Islam. In order to support this idea, Gamal alDin al-Afghani (1255-1839) called on Muslims to rally around the Ottoman caliphate represented by the Ottoman dynasty, but the fault of the Sultan was his reliance on the Sufi orders for promotion of the idea and his silence about their deviations in dogma ". 82

Jews harbored animosity to the Sultan seeking to exploit the internal and external conditions surrounding the Sultan. They, represented by Herzl, asked the Sultan to grant them Palestine as a national homeland for the Jews of the world. Herzl was able to obtain European support for his idea and offered a large sum of

\footnotetext{
${ }^{81}$ Austria called for the convening of the Berlin Conference. All major powers such as England, France, Germany, Russia and Austria were invited. The Treaty of San Stefano was amended and the terms of the Berlin Conference were discussed: the independence of Bulgaria, the annexation of Bosnia and Herzegovina to Austria, the independence of Serbia and Montenegro, annexing the cities of Kars and Russia. For more: Refer to: Aztalo Youssef Bek Asaf: The History of the Sultans of bani Othman from origins to the present, introduced by: Mohamed Zinham, Madbouli bookshop, Cairo, First Edition, 1415 H., 1995.p. 133.

Mohamed Fareed Bek The Lawyer: History of the Sublime Ottoman State, Ihsan Haqi (Ed), Dar al-Nafais, Beirut, first edition, 1401 H-1981, p. 603.

${ }^{82}$ On the idea of Pan-Islamism, refer to Anwar al-Gendi: Sultan Abdel-Hamid and the Islamic Caliphate, Al-Sunna bookshop, Cairo, First Edition, 1407 AH, p. 96: 115. Ahmad Abdulla Al-Flaij: Awakening of the Sick Man (Sultan Abdel-Hamid and the Islamic Caliphate), Sakr Foundation, Kuwait, 1984, pp. 85: 200.
} 
money, about twenty million liras, to repay debts of the state in return of ceding Palestine.

But the Sultan's response failed the hopes of Jews. it was a pride of every Muslim man, as he said: "No, I will not give up an inch of the Holy Land; it is not my property; it is the property of my people. My predecessors struggled for the sake of this land; let Jews keep their millions." All financial temptations of Jews failed; so, they took part in conspiring with all anti-Muslims forces, coordinating with all directions to overthrow the Sultan for their ambitions for Palestine. The Italian Masonic Forum, known as the Greater Orient, took care of this task ". ${ }^{83}$

The Masonic councils, along with the Jews of Dounma, ${ }^{84}$ played a role in planning the overthrow of the Sultan. They were the mastermind while Western European countries were the financiers because they had great influence among the Sublime Porte and Young Turks. Beirut had witnessed the opening of a branch of Freemasonry to depose the Sultan in 1868-1869. After 1905, the Committee of Union and Progress (CUP)_found acted freely in Salonika because of the international control there from England and France. The federalists were able to infiltrate the decision-making positions; their movement was Turanic nationalism. The parties to the plot were integrated including the Masonic and secularists, both represented the Committee of Union and Progress. European countries were represented in the Young Turks party, behind all the Jews led the conspiracy. They made use of the constitution issue suspended since 1876. The Sultan attempted to thwart the opportunity of the conspirators,

${ }^{83}$ For more on the relationship of Jews to Sultan Abdel-Hamid II, refer to Mohamed Kheir Falaha. The Ottoman Caliphate from the Cradle to the Grave, p.71-72. Hassan Ali Halaq. The role of the Jews and the international powers in dethroning Sultan Abdel-Hamid II (1908-1909), Dar al-Jami'a, Beirut, History, p. 7: 102. Rafik Shaker: Sultan Abdel-Hamid II and Palestine, p. 101: 104.

84 The Jews of Donmeh: A word means return or apostasy, religiously means a new doctrine; politically speaking, it means the Muslim Jews who have a special entity. Refer to The Ottoman Empire, p. 440. 
Sultan Abdel-Hamid's II Gift based on Family Memoirs1876-1909

but there was an incident in which a number of supporters of the Committee of Union and Progress were killed. Following this incident, forces of the Committee of Union and Progress marched from Salonika to Istanbul. They entered the Caliphate Palace and Sultan Abdel-Hamid II was deposed.

He was taken to Salonika, where he remained for several years. Three sultanas, four concubines, and an entourage of no more than thirty people were left for him. He took a cat he loved so much. In this way, Sultan Abdel-Hamid II disappeared from the horizon of politics, and brought his brother Mohammed Rashad to the throne. Dwellers of the capital suddenly found new Sultan presiding the state; Mohammed Rashad. ${ }^{85}$

\section{Conclusion}

The present paper sheds light on the era of the Ottoman Sultan Abdel-Hamid II, revealing the true nature of his policy towards the Ottoman Empire, and towards the major European hostile countries, which regarded the Ottoman Empire as a weak state no longer able of making conquests as in the past .

- This study also showed some important results in the history of that stage; Abdel-Hamid II had clear impacts in his policy in the Ottoman state by adhering to the teachings of the Islamic religion, which must be the constitution to rely upon.

- The study showed that Sultan Abdel-Hamid favored peace despite his interest in all the affairs of the army. He lacked parading the army and the status of the Ottoman Empire. This

\footnotetext{
${ }^{85}$ Mary Mills Patrick: Pages from Turkey's history. P144. Rafiq Shaker, Sultan AbdelHamid II and Palestine, p.119:123. Kamal Al-Saeed Habib: Minorities and Politics in Islamic Experience Pp. 451- 455. Sulaiman bin Saleh Al-Kharashi: How the Ottoman Empire Fell, Dar al-Qasim, Riyadh, First Edition, 1420H, pp. 48-52. Mohamed al-Nasir alNifzawi: Political Thought Currents in the Ottoman Sultanate, 1839-1918, Dar Muhammad Ali, Sfax, Tunisia, 2001, p. 404. Mahmoud Thabet Al-Shazli: The Oriental Question: A documentary study on the Ottoman Caliphate 1299-1923, Wahba bookshop, Cairo, First Edition, 1989, p. 166.
} 
Dr. Neven Mostafa Hassan Saad / Mohammed Abdullah Mushabab Aal Muzher al-Asmari

was why historical writings were unfair to him, depicting him as the sick man of Europe.

- One of the most important results of the study was revealing Abdel-Hamid's dealings with the ministers, especially Medhat Pasha. He had to understand the complex policy of the nations through the existence of a constitution; he could have done what he wanted without dissolving the parliament, keeping it formally before the West; he appeared as a despotic dictator.

- One of the most prominent results of the study is that AbdelHamid, regardless of writings of the spiteful; had the most courageous positions towards the Jews, despite the financial difficulties then experienced by the state.

- The study sheds light on the reforms of Sultan Abdul Hamid II towards the army, revealing that Abdel-Hamid was not a radical. He was adhering to the principles of the true religion that every soldier should have. Therefore, he sent missions to Germany. He was eager to prepare officers based on Islamic ethics.

- One of the most important findings of the research is that the Germans were the most loyal ally of the Ottoman Empire in the era of Sultan Abdel-Hamid II. This was why he preferred the Germans who had no designs in Turkey.

- The study also showed that the Ottoman army had its place among the armies of the European world. Maybe criticism directed to him was due to his not liking war; preferring peace to war. He also categorically rejected the admission of non-Muslims into the army as this might cause a division among the sects of the state, especially as the European countries were seeking faults in the Ottoman Empire to harm it. 


\section{Appendix}

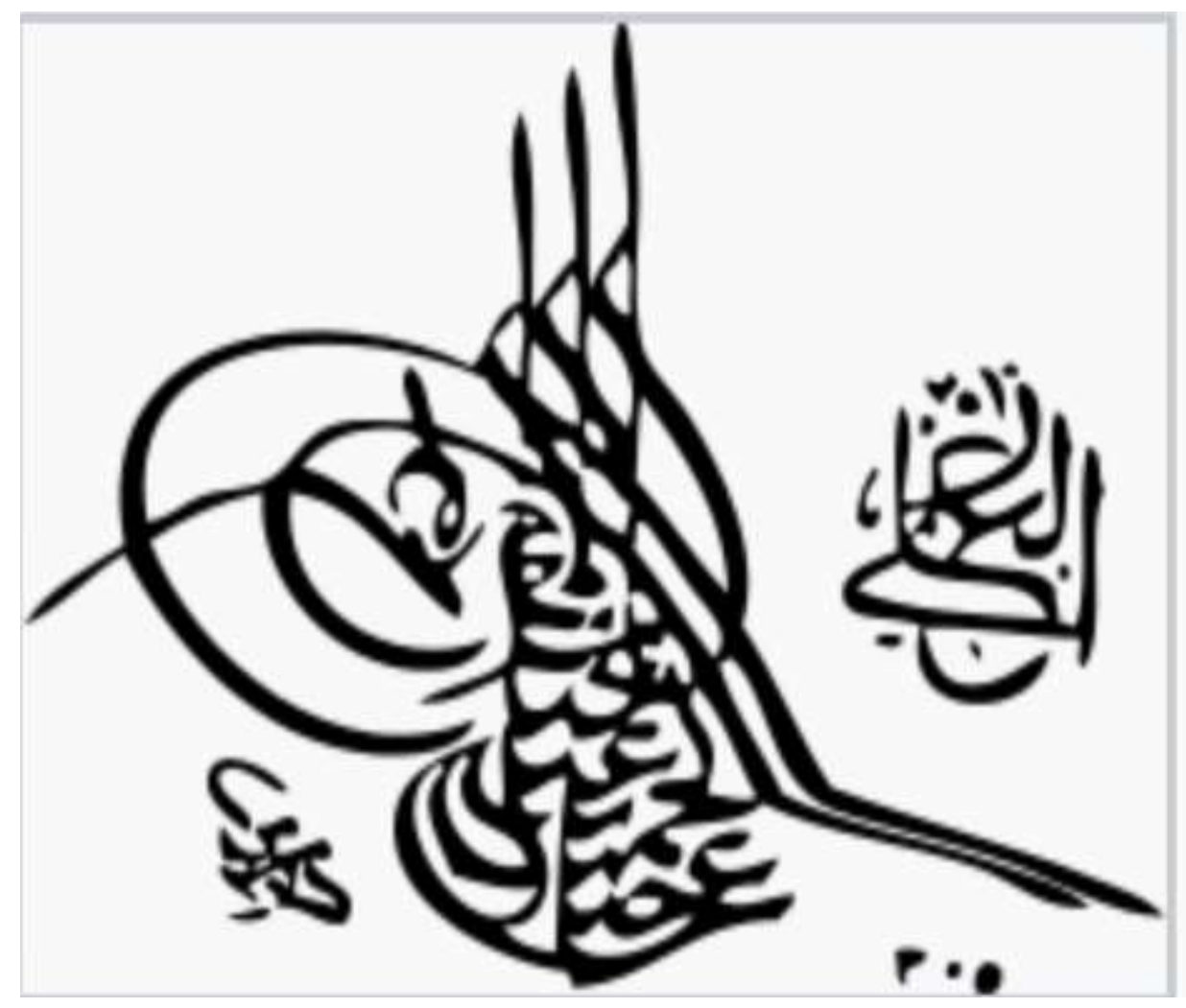




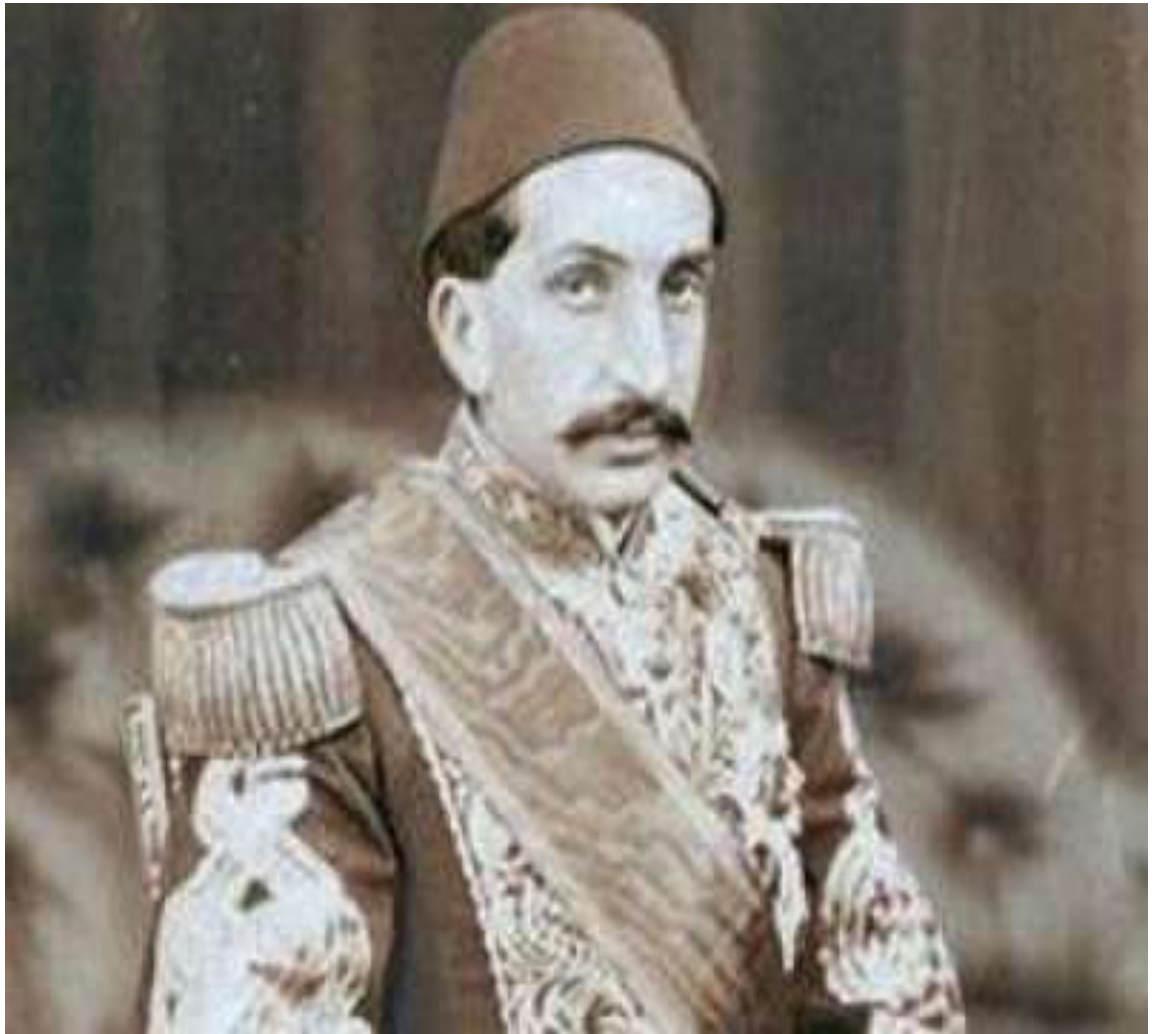

Sultan Abdel-Hamid II: 1876-1909 


\section{In the name of Allah}

We, the undersignatories, hereby certify that the rifle owned by Mohammed Bin Abdallah Bin Mashabab Aal-Mezher, is inherited, serially, by him from a grandfather to a father. Its age is more than 126 years; stamped by Sultan Abdel-Hamid's seal. It was presented to our father, Mashabab Aal-Mezher, bequeathed to our brother Abdallah and then to his son Mohammed Bin Abdullah. The Turkish delegation were hosted by the emir of Ballasmer at the time, Sheikh Ali Bin Mohammed. Father of Sheikh Abdallah Bin Ali Bin Jarman took over the sheikdom in the era of king Abdel Aziz at the time of the establishment of the Saudi state in $1341 \mathrm{AH}$. He sent a delegation of Turks to Mashabab for him to welcome them, which he did with ovation. The Sultan's advisor presented this rifle to him. It is one of the rifles of Sultan Abdel-Hamid.

May God grant us success

Witness: Mohammed Bin Mashabab Aal-Mezher Al-Asmary

Witness : Ali Bin Mashabab Aal-Mezher Al-Asmary

Fingerprint

Fingerprint

Deputy of al-Midfah Tribe

Sheikh/ Abdel-Aziz Bin Ali Bin Abdallah Aal-Jarman

Signature:

Seal: 
Pictures showing a rifle of Sultan Abdel-Hamid II, as shown by the stamp on them, written in Turkish Ottoman: "Made at guns works in Turkey."

This gun was given by Sultan Abdel-Hamid II to my grandfather Mushabab Aal Mezher, when the Sultan sent his envoy to the Asir region; during his trip he passed over the area of Balslemer in Saudi Arabia, the house of my grandfather. The mission's chief delegate gave this gun to my grandfather, for the good reception he had and securing his way, and told him that it was a gift from the Ottoman Sultan for their hospitality.

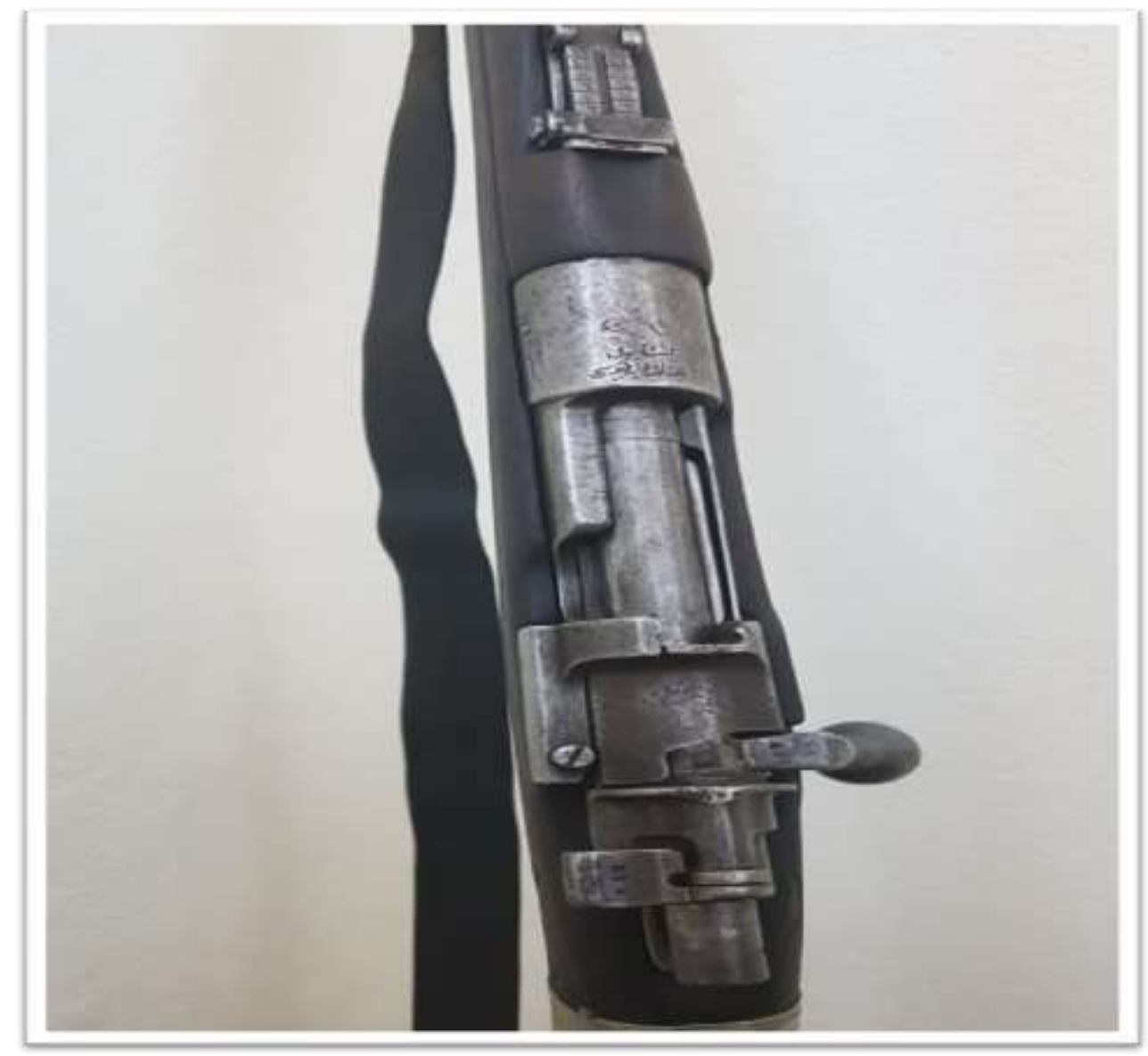


Sultan Abdel-Hamid's II Gift based on Family Memoirs1876-1909

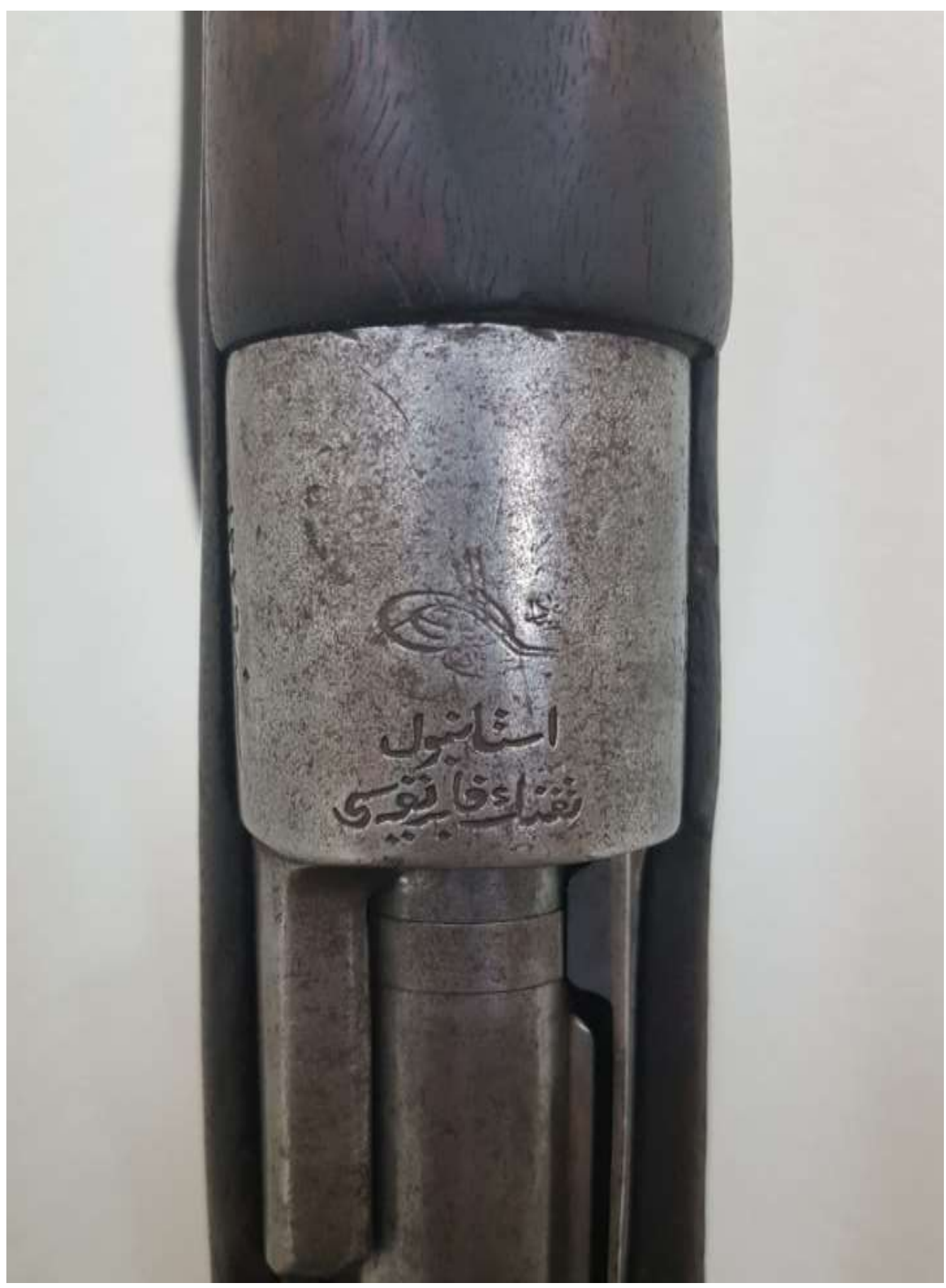

Faculty Of Arts Journal 2631 


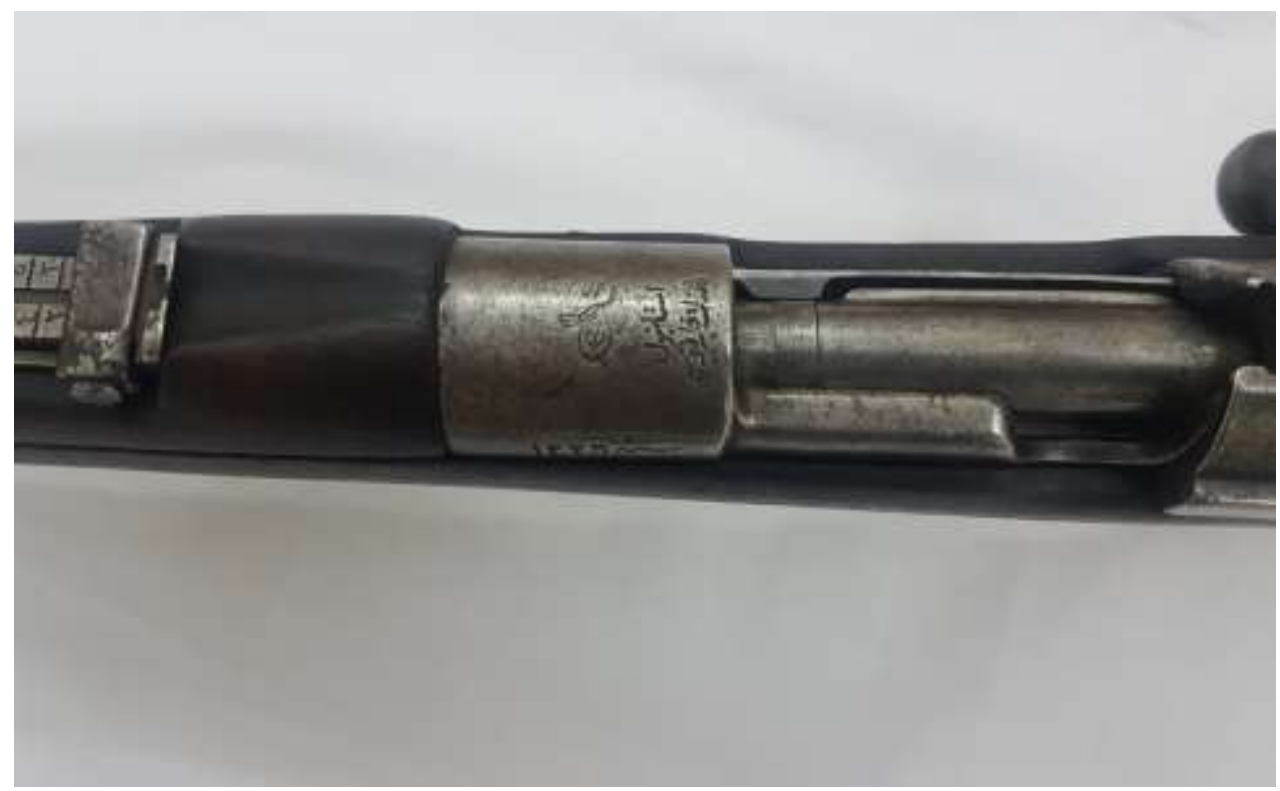


Sultan Abdel-Hamid's II Gift based on Family Memoirs1876-1909

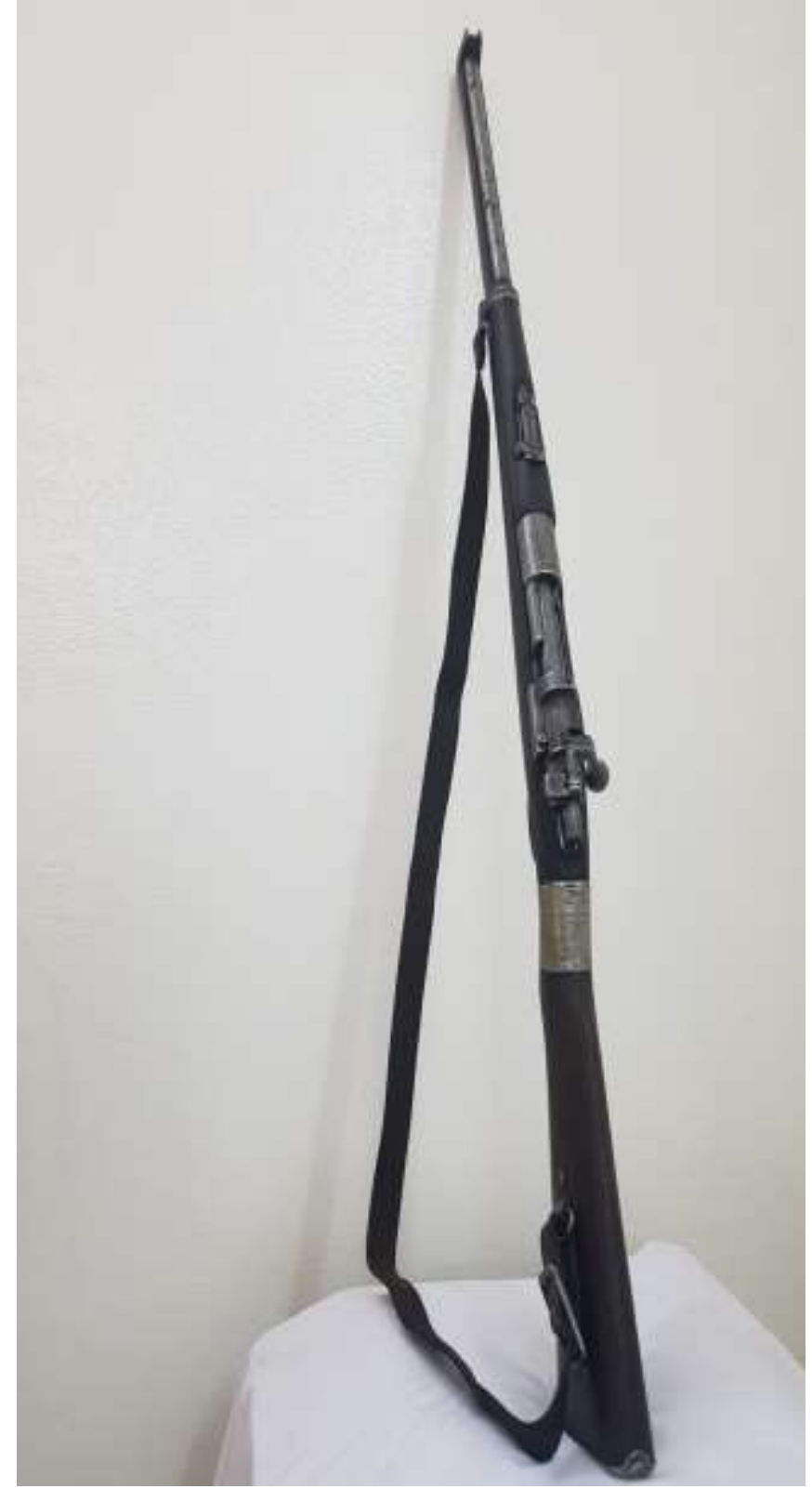

Faculty Of Arts Journal 2633 

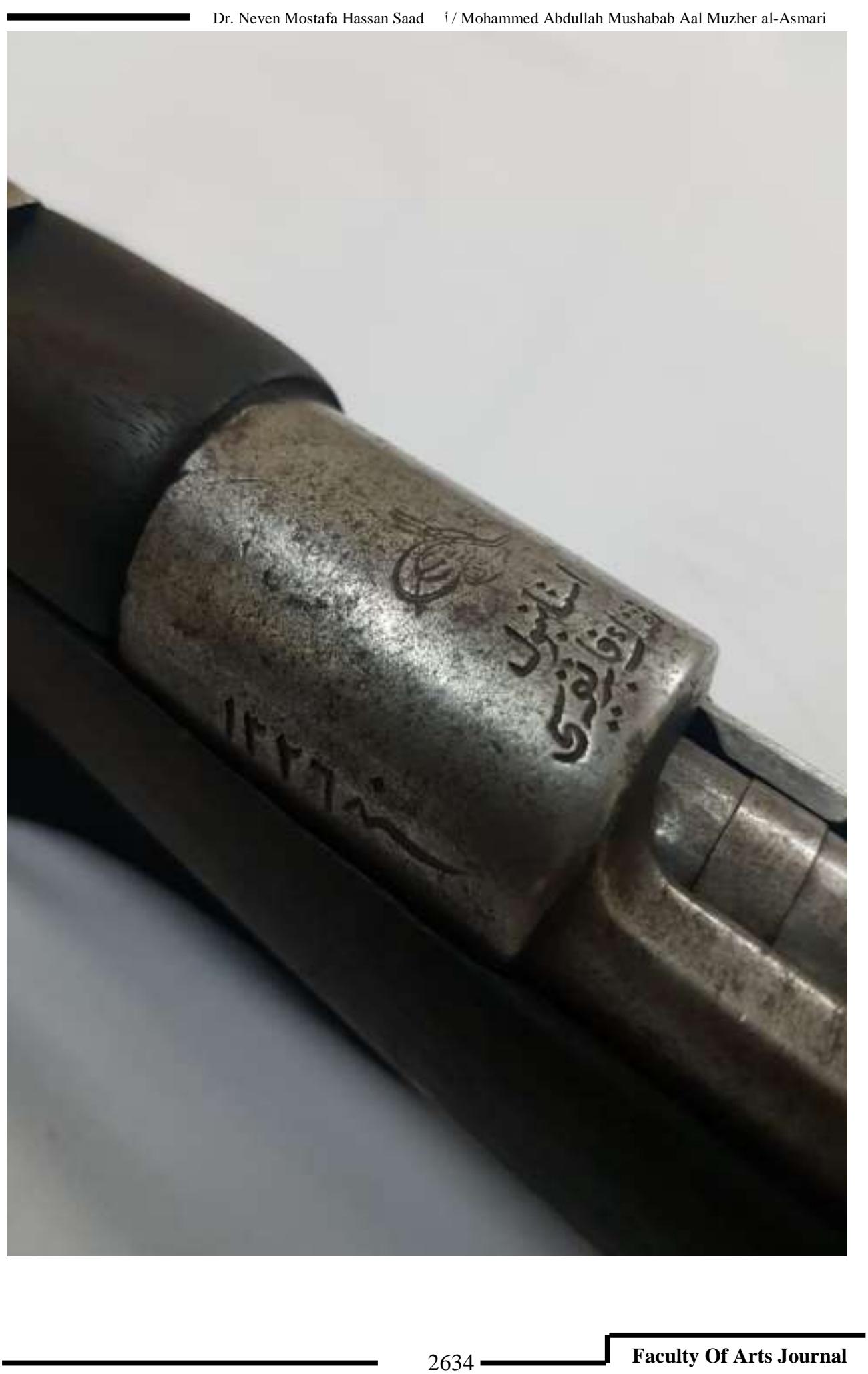
Sultan Abdel-Hamid's II Gift based on Family Memoirs1876-1909

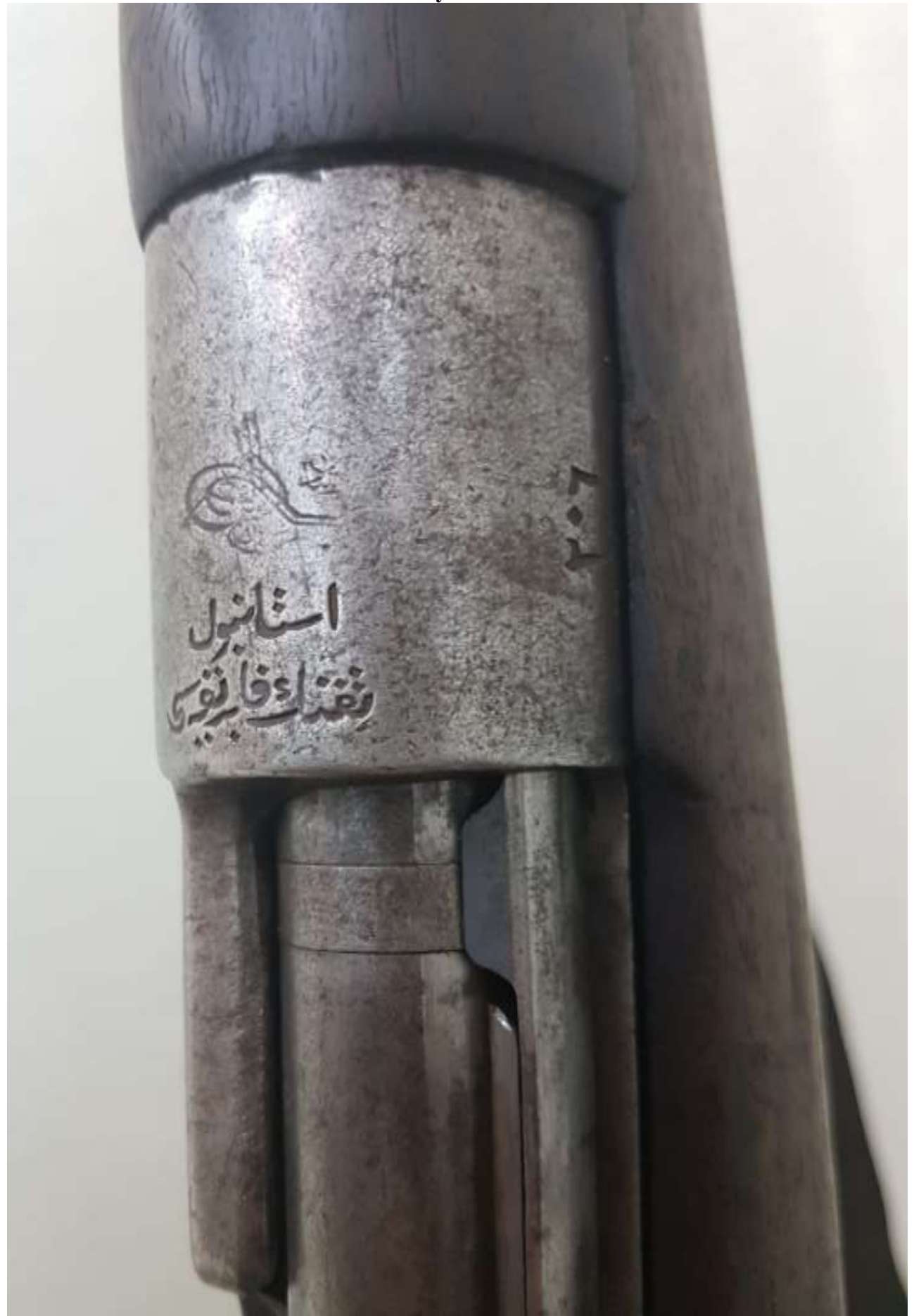

Faculty Of Arts Journal 2635 


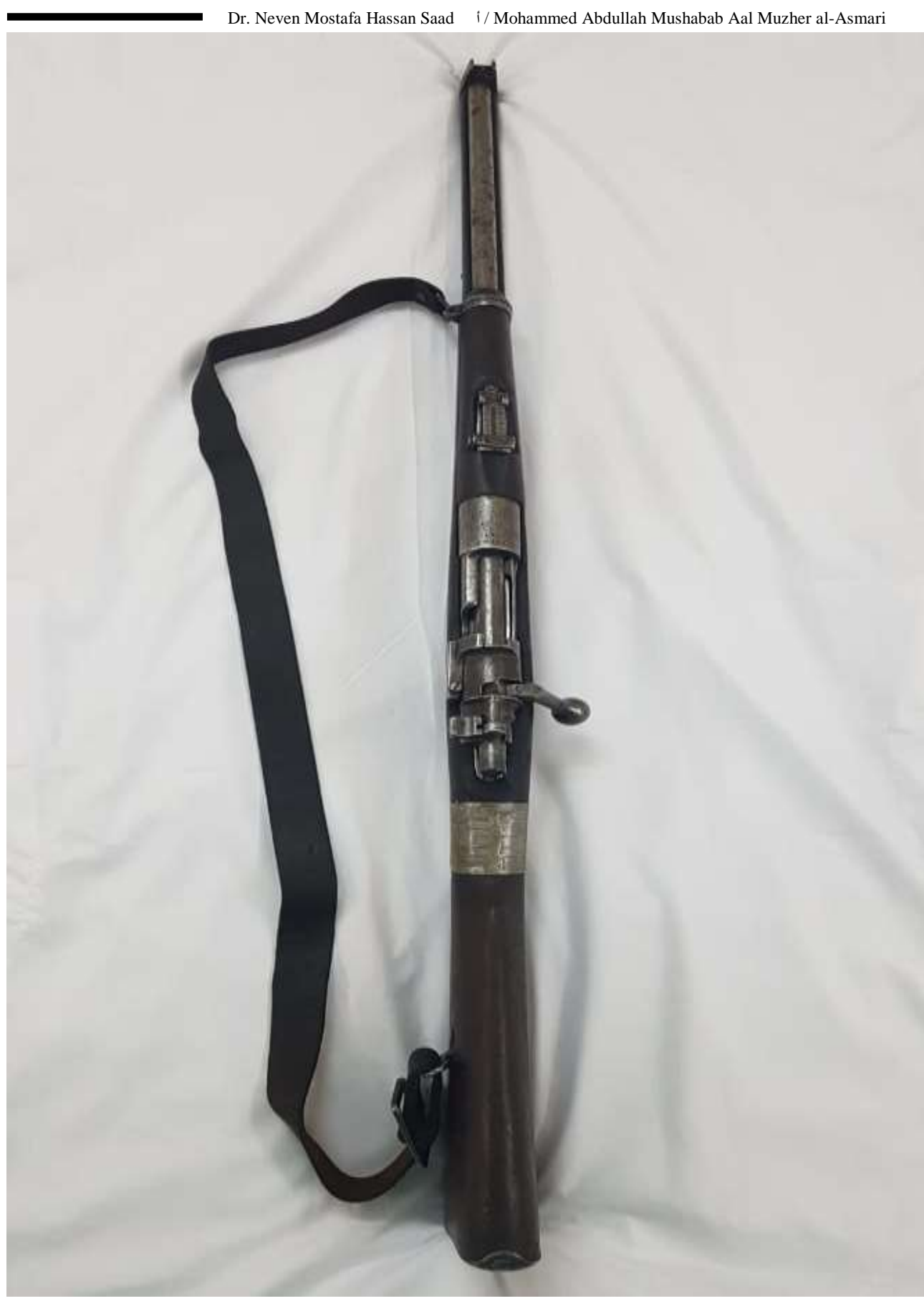


Sultan Abdel-Hamid's II Gift based on Family Memoirs1876-1909

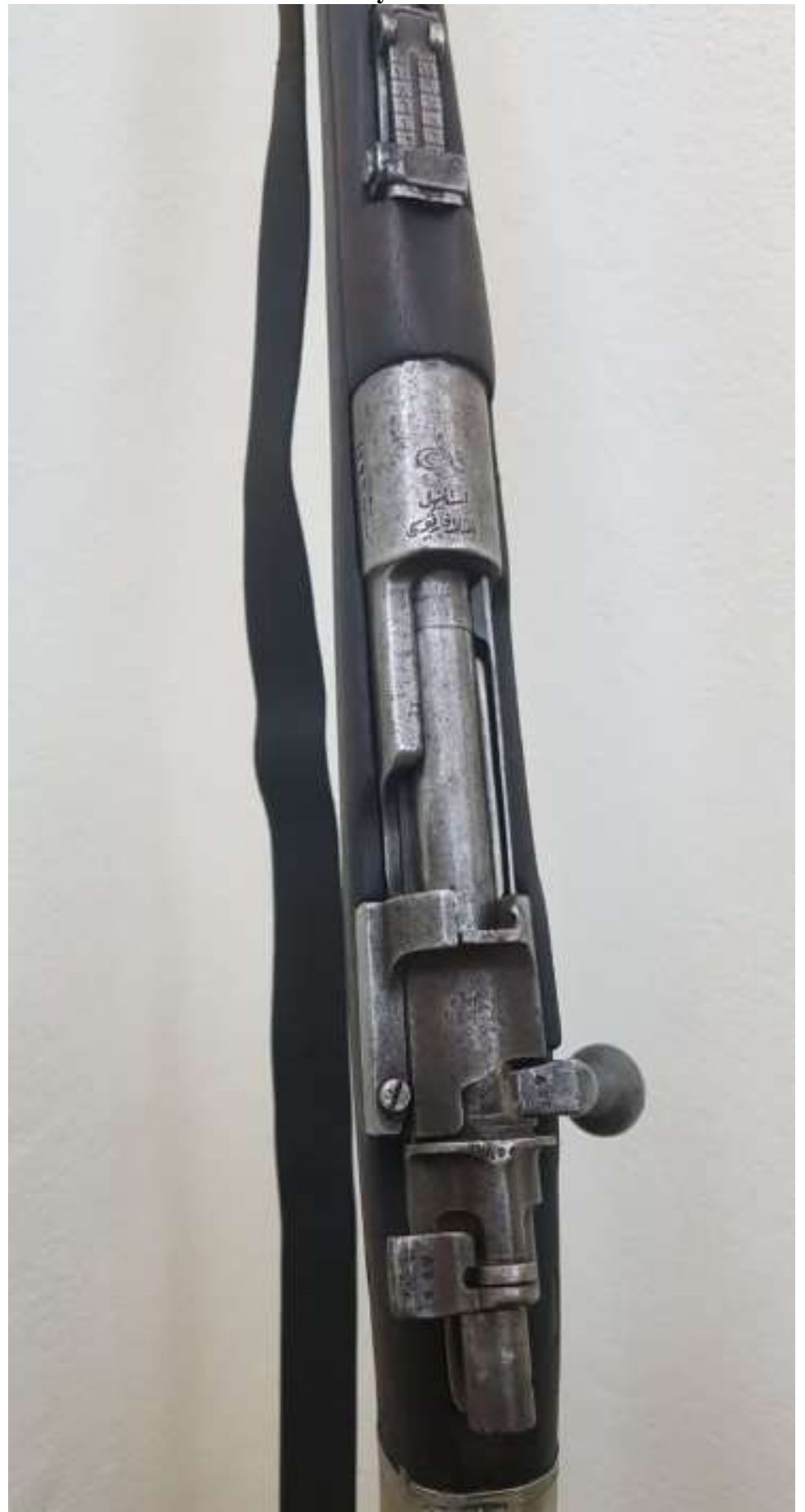

Faculty Of Arts Journal 2637 

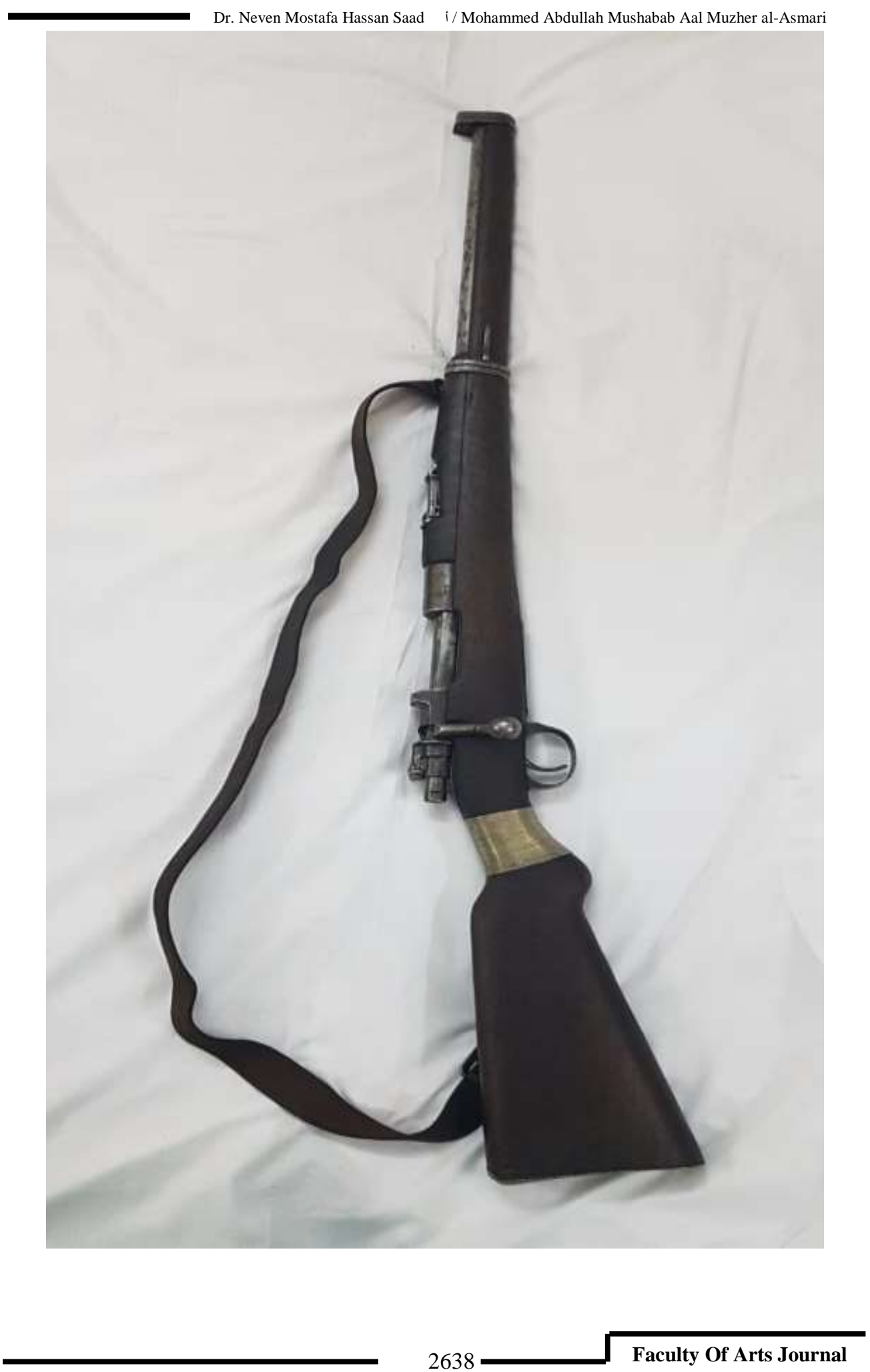
Sultan Abdel-Hamid's II Gift based on Family Memoirs1876-1909

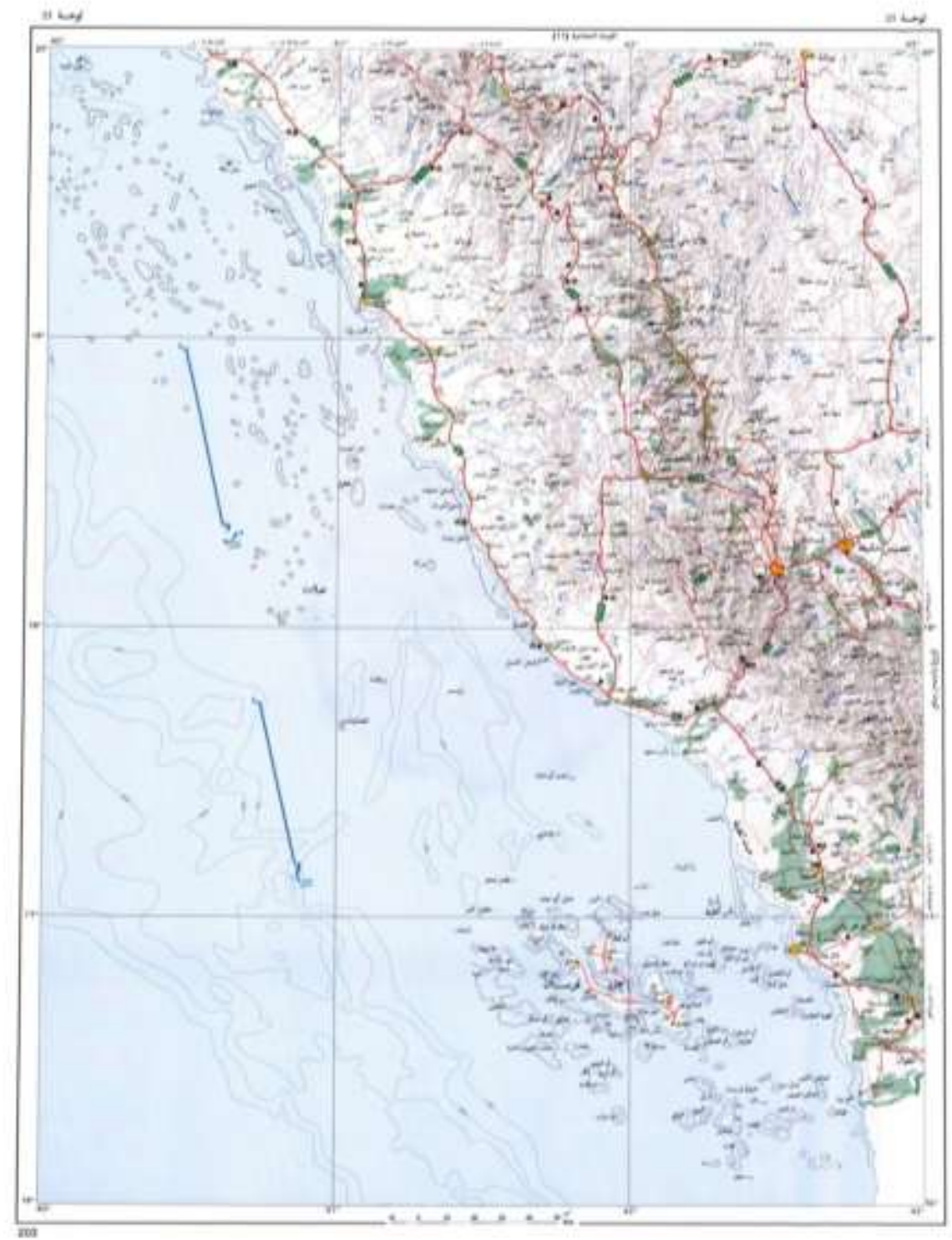




\section{References}

- Ibn Hazm, Abu Muhammad Ali bin Ahmed bin Said bin Hazm al-Andalusi (d.456 AH). Lineage of the Arabs, Dar al-Kittab alAlami, Beirut, $1^{\text {st }}$ ed, 1983.

-Ibrahim Bek Halim: History of the Ottoman Empire, known as The book of Halimi masterpiece in the history of the sublime state, Cultural Books Foundation (al-kotob al-thaqafiya), Beirut, first edition, 1408 - 1988.

- Ahmed Abdul-Rahim Mustafa: On Origins of Ottoman History, Dar Al-Shorouk, Cairo, $3^{\text {rd }}$ edition, 2003.

- Ismail Ahmed Yaghi: The Islamic State in Modern Islamic History, Obeikan, Riyadh, First Edition, 1416H - 1996.

-Anwar al-Jendi: Sultan Abdel-Hamid and the Islamic Caliphate, Al-Sunna bookshop, Cairo, first edition, 1407 AH.

- Orhan Mohammed Ali: Sultan Abdel-Hamid II and the Events of his Reign, Istanbul, 2008.

- Bader Mohammed Abdelaziz Badr: Ottoman Firearms at the Levantine Museum in Nicosia and the Middle Ages in Limassol, Cyprus "A Comparative Archaeological Artistic Study", Proceedings of the Fifteenth Congress of the General Union of Arab Archaeologists, Jeddah, 1 st, 2012.

- Gamal Abdul Hadi Masoud et al: Errors that must be corrected in history: The Ottoman Empire, Part Two, Dar Al-Wafaa, First Edition, 1416H-1995.

- John Patrick: The Ottoman Centuries, The Rise and Fall of the Turkish Empire. Nahed Ibrahim Desouki, (Translator). AlMaaref Establishment, Alexandria, 2002.

- Hassan Ali Halaq: The role of the Jews and international forces in the dethroning of Sultan Abdel-Hamid II (1908-1909), University House, Beirut, Lebanon, no date.

- Rafiq Shaker al-Natsha: Sultan Abdel-Hamid II and Palestine, Arab Institute for Studies and Publishing, Beirut, third edition, 1991. 
Sultan Abdel-Hamid's II Gift based on Family Memoirs1876-1909

- Robert Mantrand: History of the Ottoman Empire, Part II, Translated by: Bashir Al-Sibai, Dar Al-Fikr, Cairo, First Edition, 1993.

- Sultan Abdel-Hamid II: My Political Notes (1891-1908), alResala Foundation, Beirut, Lebanon, $2^{\text {nd }}$ edition, 1399 - 1979.

- Sulayman bin Saleh al-Kharashi: How the Ottoman Empire fell, Dar al-Qasim, Riyadh, first edition, 1420.

- Seham Mohamed Hindawi: The Historical Development of Ottoman German Relations (1293 AH - 1327H - 1876/1909) Confidential Documents, Dar Ninawa for Studies, Publishing and Distribution, $1^{\text {st }}$ ed, Syria, Damascus.

- Suhail Saban: Arms Trade in the Arabian Peninsula and the Gulf from the Ottoman Archive, 1898-1910, King Fahd National Library, Vol. 10, $2^{\text {nd }}$ ed, 2005.

- Abdul Aziz Mohamed Al-Shennawi: The Ottoman Empire, a calumniated Islamic State, part 1, the Anglo-Egyptian bookshop, Cairo, 1980.

- Abdel Aziz Mohamed Awad: Ottoman Administration in the State of Syria 1864-1914, Dar Al Ma'arif, Egypt, 1969.

- Azotlo Youssef Bek Asaf: The History of the Sultans of Bani Othman from Origins to present, introduced by: Mohamed Zainham, Madbouli bookshop, Cairo, First Edition, 1415H.

-Ali Mohammed Al-Salabi: The Ottoman State: Factors of Promotion and Causes of Fall, Islamic House for Distribution and Publishing, First Edition, 1421 AH-2001.

- Kamal Al-Saeed Habib: Minorities and Politics in Islamic Experience from the Beginning of the Prophetic State to the End of the Ottoman Empire (621-1908), Madbouli bookshop, First Edition, 2002.

- Mary Mills Patrick: Pages from Turkey's social, political and Islamic history, Izz al-Din Foundation, first edition, $1407 \mathrm{H}-$ 1986.

Mohamed Kheir Falaha: The Ottoman Caliphate from the Cradle to the Grave: (an objective study showing states of sultans and 
their civilization of decorating, followed by rashness of the reckless, 2005.

Mohamed Fareed Bek The Lawyer: History of the Sublime Ottoman State, Ihsan Haqi (Ed), Dar al-Nafais, Beirut, first edition, $1401 \mathrm{H}-1981$.

- Muhammad Mahmoud Al-Jahini: Art of Gun Decoration in the Ottoman Period, Journal of the Faculty of Archeology, South Valley University, Qena, issue 6, 2011.

- Mohamed al-Nasir al-Nifzawi: Political Thought Currents in the Ottoman Sultanate, 1839-1918, Dar Muhammad Ali, Sfax, Tunisia, 2001.

- Mahmoud Shaker, The Arabian Peninsula "Asir", al-Maktab Al-Islami, Damascus.

- Mahmoud Thabet Al-Shazli: The Oriental Question: a Documentary Study on the Ottoman Caliphate 1299-1923, Wahba bookshop, Cairo, First Edition, 1989.

- Memoirs of Princess Aisha Osman Ogli: My Father Sultan Abdel-Hamid II,: Saleh Saadawi, (translator). Dar al-Bashir, $1^{\text {st }}$ edition, 1411 AH-1991.

Muwafaq Bany Al-Marja. Ahmad Abdullah Al-Flaij (Ed). Awakening of the sick man (Sultan Abdel-Hamid II and the Islamic Caliphate), Saqr Foundation, Kuwait, 1984.

- Nahed Ibrahim Desouki: The Ottoman centuries: The Rise and Fall of the Empire, al-Ma'arif Establishment, Alexandria, 2002.

Yilmaz Ozatuna: Encyclopedia of the Political, Military and Cultural History of the Ottoman Empire, Vol. III, Translated by: Adnan Salman, Arab House for Encyclopedias, First Edition, $1431 \mathrm{H}: 2010$.

University theses:

- Ali Ahmed Abbas: Sultan Abdel-Hamid II 1293 - 1326 AH / 1876-1909, unpublished doctoral dissertation, Faculty of Education, University of Omdurman, Sudan, 2017. 
Sultan Abdel-Hamid's II Gift based on Family Memoirs1876-1909

- Yusuf Omar Habib: Reasons for Dethroning of Sultan AbdelHamid II 1876-1909, unpublished MA Thesis, Faculty of Arts, Yarmouk University, Jordan, 2000.

Periodicals:

- Amani Jaafar al-Ghazi: Sultan Abdel-Hamid II the calumniated and his position from the hijab (veil) of women. An analytical historical study, Journal of Oriental Studies, issue 55, 2015.

- Makram Abdul-Fattah Abdul-Khaliq: An Ottoman document on the Ottoman-German relations during the reign of Sultan AbdelHamid II, study and translation, Journal of the Faculty of Languages and Translation, Al-Azhar University, issue 31, 2000. Oral accounts:

- Interview with Mohammed Abdullah Mushabab Aal Muzher alAsmari from Balasmer tribe. 